\title{
Addressing the Contribution of Indirect Potable Reuse to Inland Freshwater Salinization
}

\section{Shantanu Bhide}

Virginia Tech https://orcid.org/0000-0002-5248-0646

Stanley Grant ( $\nabla$ stanleyg@vt.edu )

stanleyg@vt.edu https://orcid.org/0000-0001-6221-7211

\section{Emily Parker}

Virginia Tech https://orcid.org/0000-0002-8299-9908

\section{Megan Rippy}

Virginia Tech

\section{Adil Godrej}

Virginia Tech https://orcid.org/0000-0003-2609-8336

\section{Sujay Kaushal}

University of Maryland

\section{Greg Prelewicz}

Fairfax Water

Niffy Saji

Fairfax Water

Shannon Curtis

Fairfax County

\section{Peter Vikesland}

Virginia Tech https://orcid.org/0000-0003-2654-5132

\section{Ayella Maile-Moskowitz}

Virginia Tech

Marc Edwards

Virginia Tech

Kathryn Lopez

Virginia Tech

Thomas Birkland

Virginia Tech

Todd Schenk

Virginia Tech 
Keywords: freshwater salinization syndrome (FSS), sodium

Posted Date: September 24th, 2020

DOI: https://doi.org/10.21203/rs.3.rs-60678/v1

License: (c) (1) This work is licensed under a Creative Commons Attribution 4.0 International License. Read Full License

Version of Record: A version of this preprint was published at Nature Sustainability on April 19th, 2021. See the published version at https://doi.org/10.1038/s41893-021-00713-7. 


\title{
Addressing the Contribution of Indirect Potable Reuse to Inland Freshwater Salinization
}

\author{
Shantanu V. Bhide ${ }^{1}$, Stanley B. Grant ${ }^{* 1,2}$, Emily A. Parker ${ }^{1}$, Megan A. Rippy ${ }^{1,2}$, Adil Godrej ${ }^{1}$, \\ Sujay Kaushal ${ }^{3}$, Greg Prelewicz ${ }^{4}$, Niffy $\mathrm{Saji}^{4}$, Shannon Curtis ${ }^{5}$, Peter Vikesland ${ }^{6}$, Ayella Maile- \\ Moskowitz ${ }^{6}$, Marc Edwards ${ }^{6}$, Kathryn Lopez $^{6}$, Thomas A. Birkland ${ }^{7}$, Todd Schenk ${ }^{2,8}$
}

\section{A Manuscript for Nature Sustainability}

${ }^{1}$ Occoquan Watershed Monitoring Laboratory, The Charles E. Via, Jr. Department of Civil and Environmental Engineering, Virginia Tech, 9408 Prince William Street, Manassas VA, 20110 USA.

${ }^{2}$ Center for Coastal Studies, Virginia Tech, 1068A Derring Hall, 926 West Campus Drive, Blacksburg, VA 24061 USA.

${ }^{3}$ Department of Geology \& Earth System Science Interdisciplinary Center, University of Maryland, College Park MD, 20740 USA.

${ }^{4}$ Fairfax Water, 8560 Arlington Blvd., Fairfax VA 22031 USA.

${ }^{5}$ Fairfax County Stormwater Planning Division, Dept. Public Works and Environmental Services, 12000 Government Center Parkway, Suite 448., Fairfax VA 22035 USA.

${ }^{6}$ The Charles E. Via, Jr. Department of Civil and Environmental Engineering, 200 Patton Hall, Virginia Tech, 750 Drillfield Drive, Blacksburg VA, 24061 USA.

${ }^{7}$ College of Humanities and Social Sciences, North Carolina State University, 2526 Hillsborough Street, Suite 102, Raleigh NC 27607 USA.

${ }^{8}$ Urban Affairs and Planning, School of Public and International Affairs, 212 Architecture Annex, Virginia Tech, 140 Otey Street NW, Blacksburg VA 24061 USA.

*Corresponding author: stanleyg@vt.edu; ORCID ID: 0001-6221-7211 


\begin{abstract}
Inland freshwater salinity is on the rise in many regions across the globe - a phenomenon called the freshwater salinization syndrome (FSS). In this paper we investigate a potential conflict between managing the FSS and indirect potable reuse, the practice of augmenting water supplies through the addition of reclaimed wastewater to surface waters and groundwaters. From timeseries data collected over the past 25 years, we quantify the contributions of three salinity sources - a wastewater reclamation facility and two rapidly urbanizing watersheds - to the rising concentration of sodium (a major ion associated with the FSS) in a regionally important drinking water reservoir in the Mid-Atlantic United States. Sodium mass loading to the reservoir is primarily from watershed runoff during wet weather periods and reclaimed wastewater during dry weather periods. Across all timescales evaluated, sodium concentration in the reclaimed wastewater is higher than in outflow from the two watersheds. Sodium in reclaimed wastewater originates from chemicals added during wastewater treatment, industrial and commercial discharges, human excretion, and down drain disposal of drinking water and sodium-rich household products. Thus, numerous opportunities exist to reduce the contribution of indirect potable reuse to sodium pollution at this site, and the FSS more generally. On the ground implementation will require deliberative engagement with a diverse community of watershed stakeholders and careful consideration of the local political, social, and environmental context.
\end{abstract}




\section{Introduction}

While historically a problem only in areas of the world with arid and semi-arid climates, poor agricultural drainage practices, sodic sub-soils or saline shallow groundwater [1-3], inland freshwater salinization is now on the rise in many cold and temperate regions of the United States (US) [4-8]. This trend is particularly notable in the densely populated Northeast and MidAtlantic [9-12] and agricultural Midwest regions $[8,13,14]$ of the country. Globally, inland freshwater salinization has been reported in Canada, Finland, France, Greece, Italy, Iran, and Russia [15]. Ions associated with inland freshwater salinization vary by location and source, but generally include a subset of the so-called major ions (defined here as $\mathrm{Na}^{+}, \mathrm{Ca}^{2+}, \mathrm{Mg}^{2+}, \mathrm{K}^{+}, \mathrm{Cl}^{-}$, $\mathrm{SO}_{4}^{-2}$ ) [5]. Indeed, rising freshwater salinity is part of a broader change in the chemistry of many of earth's inland freshwaters - including rising $\mathrm{pH}$, alkalinity and base cation concentrationdescribed by Kaushal and co-workers as the "Freshwater Salinization Syndrome" (FSS) [8]. Human drivers include the use of deicers on roads and parking lots [9,16-20], water softener use [12], wastewater and industrial discharges [21], fertilizers and pesticides [22], the weathering of concrete $[9,23-26]$, and the accelerated weathering of geologic materials from the release of strong acids and human excavation of rock, which currently exceeds natural denudation processes by an order of magnitude [27,28]. In a recent modeling study, Olson [13] predicts that specific conductance (one measure of salinity) will increase $>50 \%$ in more than half of U.S. streams by 2100 .

The FSS is a direct assault on freshwater ecosystems and human water security. Chloride enrichment of streams is associated with declines in pollution-intolerant benthic invertebrates and loss of critical freshwater habitat [29]. Stream borne salts displace previously sequestered contaminants (e.g., nutrients and heavy metals) mobilizing them into sensitive ecosystems and drinking water supplies $[15,17,30,31]$ and potentially reversing hard won pollution reductions. 
Rising salinity threatens regionally important drinking water supplies [32] by mobilizing lead, copper and other heavy metals from aging drinking water infrastructure through cation exchange and corrosion [32-35]. Increased salinity also alters the perception of potability—at high enough concentrations, sodium and other salts degrade the taste of drinking water [36]. The World Health Organization and the U.S. Environmental Protection Agency (EPA) have set taste thresholds for the concentration of sodium in drinking water of $200(\mathrm{NaCl} \mathrm{mg}) / \mathrm{L}$ (about 78.6 $\left.\left(\mathrm{Na}^{+} \mathrm{mg}\right) / \mathrm{L}\right)$ and between 30 to $60\left(\mathrm{Na}^{+} \mathrm{mg}\right) / \mathrm{L}$, respectively [37,38]. The U.S. EPA issued a drinking water health advisory for individuals on sodium restricted diets of $20\left(\mathrm{Na}^{+} \mathrm{mg}\right) / \mathrm{L}$ $[36,38]$.

In this paper, we explore a potential conflict between two important sustainability goals: (1) minimizing or reversing the FSS and (2) augmenting water supplies through the addition of highly treated wastewater to surface waters and groundwaters, a practice sometimes referred to as "indirect potable reuse" (IPR) [39]. While the number of IPR facilities is modest at present [40-42], the US Environmental Protection Agency recently released a draft national Water Reuse Action Plan $[43,44]$ that promotes IPR and other forms of wastewater reuse and recycling to address, where appropriate, expected water supply shortfalls over the next ten years in 40 of 50 US States [45]. Much more common is unplanned wastewater reuse which occurs, for example, when treated wastewater is discharged to surface waters upstream of a drinking water intake [39]. Rice et al. [46] estimated that wastewater contributes $>50 \%$ of the flow in 900 streams across the contiguous US. Even in water-rich areas of the country, such as Indiana, unplanned wastewater reuse constitutes a sizeable fraction of the water supply $(3-134 \%$, with the larger end of the range referring to circulation of wastewater through multiple water systems as it flows downstream) [47]. 
IPR, unplanned wastewater reuse, and the discharge of treated wastewater to inland freshwaters more generally, all have the potential to exacerbate the FSS because salt entering the sewage collection system, or added during the treatment process, is not removed by conventional wastewater treatment processes. However, the literature is mixed on whether treated wastewater is a significant cause of freshwater salinization $[48,49]$. For example, in a study of salt retention in a rural watershed in New York State, "salt used for deicing accounted for $91 \%$ of the sodium chloride input to the watershed, while sewage and water softeners accounted for less than $10 \%$ of the input" [12]. On the other hand, a study of sodium and chloride surface water exports from the Dallas/Fort Worth region of Texas found that, "the single largest contributor was wastewater effluent..." [21]. A reasonable inference from these and other studies is that treated wastewater is a significant source of freshwater salinity in warmer climates, while deicers drive freshwater salinization in colder climates with seasonal frozen precipitation $[10,12,18,21,50-56]$. This conclusion is supported by the strong south-to-north increasing trend in stream specific conductance along the US east coast [16]. Across all climates, untreated wastewater also drives the FSS, as documented by the contribution of aging sanitary infrastructure to stream chloride concentrations in Baltimore and Puerto Rico [57-59].

We hypothesize that some of the mixed message in the literature on the contribution of treated wastewater to the FSS arises from two methodological shortcomings: (1) the research focus has been on salt mass loading (i.e., salt mass per time) while salt concentration is also a concern (e.g., relative to the US EPA acute and chronic criteria for instream chloride concentrations [60] and the aforementioned taste thresholds and health advisory for sodium concentration in drinking water [36-38]); and (2) salt mass loads are typically reported as annual averages while the contribution of wastewater to freshwater salinization is likely to vary day-to- 
day depending on local weather conditions which can affect the dilution of wastewater flows in inland freshwaters [61-64]. We test this hypothesis by analyzing a unique $>25$-year time series of flow and sodium concentration measurements in the tributaries and reclaimed wastewater that collectively drain to the regionally important Occoquan drinking water reservoir in Northern Virginia. We quantify, using regression and a copula-based conditional probability analysis [65], how sodium inputs to the reservoir from watershed and reclaimed wastewater sources are modulated by climate and other environmental factors, and then explore how the contributions of treated wastewater to inland freshwater salinization might be reduced through locally tailored interventions that increase a region's "salt productivity."

\section{Field Site}

The Occoquan Reservoir, located approximately $30 \mathrm{~km}$ southwest of Washington D.C. in Northern Virginia, is one of two primary sources of water supply for nearly 2 million people in Fairfax County, Virginia, and surrounding communities (Figure 1a). Sodium concentration in the reservoir began increasing around 1995 (yellow curve in Figure 1b) and now frequently exceeds the US EPA's lower taste and health advisory thresholds (horizontal black solid and dashed lines). This trend prompted the local water purveyor, Fairfax Water, to explore planning-level options to address the rising sodium concentration in the reservoir, including the possible construction of a reverse osmosis treatment upgrade. The irony of "desalinating freshwater" and the estimated cost (\$1B USD, not including operating and maintenance costs and a vastly higher carbon footprint) makes identifying, and ideally mitigating, sources of sodium in the reservoir a top regional priority.

On an annual basis, approximately $95 \%$ of the water flowing into the reservoir comes from its Occoquan River and Bull Run tributaries. Water from Bull Run includes baseflow and stormwater runoff from the Bull Run watershed $\left(1.94 \times 10^{8} \mathrm{~m}^{3}\right.$ year-1) together with reclaimed 

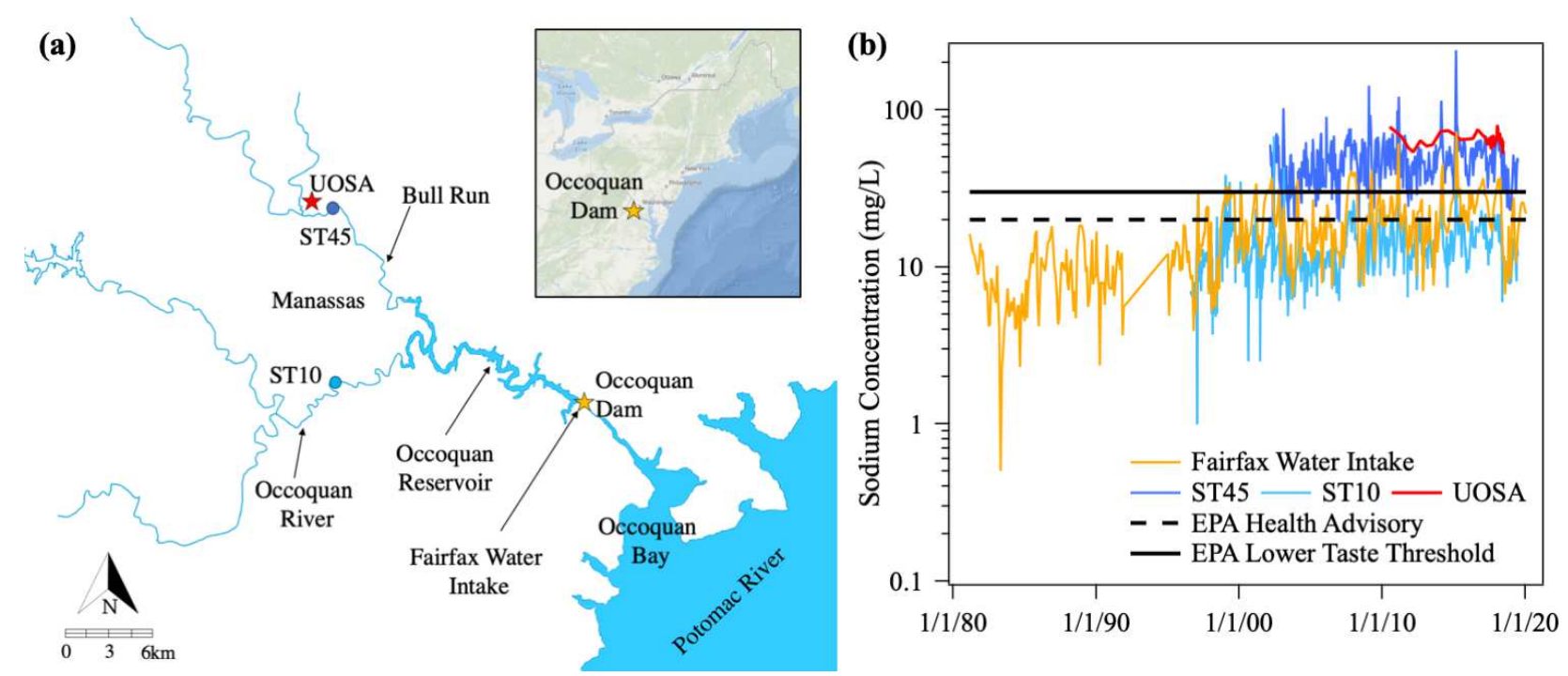

Figure 1. (a) The Occoquan Reservoir in Northern Virginia, USA. More than $95 \%$ freshwater inflow to the reservoir is from the Occoquan River and Bull Run which drain mixed undeveloped, agriculture, ex urban and urban landscapes. Shown are key geographical features including the Occoquan Dam (where Fairfax Water sources its raw water), ion and flow monitoring sampling sites on the Occoquan River and Bull Run (monitoring stations ST10 and ST45), and the location on Bull Run where reclaimed water is discharged from the Upper Occoquan Service Authority (UOSA). Water from the Occoquan Reservoir is treated by Fairfax Water, the water wholesaler, and from there passes to various water distributors. (b) Forty years of sodium concentration measurements at the Fairfax Water intake and upstream stations ST10, ST45), and the final reclaimed water discharged by UOSA. Also shown are the EPA Health Advisory and Lower Taste Threshold for sodium.

water discharged from a wastewater reclamation facility (Upper Occoquan Service Authority, UOSA) $\left(3.28 \times 10^{7} \mathrm{~m}^{3}\right.$ year-1) located approximately $1.5 \mathrm{~km}$ upstream of Bull Run's confluence with the reservoir (red star in Figure 1a). One of UOSA's missions is to improve drinking water security in the region by augmenting streamflow into the Occoquan Reservoir with a high quality and drought proof source of water. Conceived and built in the 1970s, UOSA was the US's first planned application of IPR for surface water augmentation and a model for the design and construction of similar reclamation facilities around the world $[39,66]$. Water discharged from the Occoquan River comes primarily from baseflow and stormwater runoff from the Occoquan River Watershed $\left(3.43 \times 10^{8} \mathrm{~m}^{3}\right.$ year-1). Thus, possible sources of sodium in the reservoir include deicer use and other land-based anthropogenic sodium sources in the rapidly urbanizing Occoquan River and Bull Run watersheds, which have experienced population increases of 
200,000 and 220,000, respectively, over the past 20 years [67], and salt added to UOSA's sewershed from its $>350,000$ residential and commercial connections [68]. Possible sources of sodium within UOSA's sewershed include the down-drain disposal of sodium-containing drinking water and sodium-containing household products [69-71], as well as permitted and nonpermitted sodium discharges from industrial and commercial customers. The sodium concentration in UOSA's effluent may also be elevated due to structural and non-structural water conservation measures that concentrate salts in wastewater streams [72,73]. Indeed, sodium concentration measured in daily flow-weighted composite samples of UOSA's discharge are consistently higher than sodium concentrations measured in grab samples collected downstream on the Bull Run at station ST45 and on the Occoquan River at station ST10 (Figure 1b).

\section{Results}

MLR Models for Sodium Concentration. Multiple linear regression (MLR) models of sodium concentration generated for each monitoring station (ST10, ST45, and UOSA) were ranked by Bayesian Information Criterion (BIC) and then validated using leave-one-out cross validation root mean square error (LOOCV-RMSE) and the hold-out method [74-78] (see Methods and SI for details). The top-ranked MLR models are significant $(\mathrm{p}<0.001)$ and capture between 31 and $87 \%$ of the measured variance in log-transformed sodium concentration (adjusted $\mathrm{R}^{2}$ values reported in Table 1). The top-ranked MLR model for sodium concentration at ST45 captures the most variance $\left(\mathrm{R}^{2}=87 \%\right.$, hold-out $\left.\mathrm{R}^{2}=81 \%\right)$ and its predictor variables include in situ specific conductance (positive correlation), maximum snow depth over the previous two weeks (positive correlation), log-transformed flow (negative correlation) and season (higher sodium concentration during the winter season). The top-ranked MLR model for sodium concentration in UOSA's discharge captures the second most variance $\left(\mathrm{R}^{2}=54 \%\right.$, LOOCV- $\left.\mathrm{R}^{2}=51.6 \%\right)$ and has as its only predictor variable specific conductance measured on flow-weighted composite final 
discharge samples (positive correlation). The top-ranked MLR model for sodium concentration at ST10 explains the least variance $\left(\mathrm{R}^{2}=31 \%\right.$, hold-out $\left.\mathrm{R}^{2}=15 \%\right)$, presumably because in situ specific conductance measurements were not available at this station. Predictor variables for sodium concentration at ST10 include log-transformed flow (negative correlation), maximum snow depth over the previous two weeks (positive correlation), and number of days below freezing in the previous two weeks (positive correlation). In summary, sodium concentration at these three stations is: (1) positively correlated with specific conductance measured either in situ (ST45) or on flow weighted composites of the final discharge (UOSA); (2) positively correlated with environmental variables (antecedent snow, freezing weather and winter season) likely to be associated with deicer use (ST10 and ST45); and (3) negatively correlated with flow (ST10 and ST45), implying that stormwater tends to dilute instream sodium concentration.

Table 1. Top-ranked MLR models of Sodium Concentration at ST10, ST45, and UOSA.

\begin{tabular}{|l|c|c|c|}
\hline Model Information & ST10 & ST45 & UOSA \\
\hline No. of observations & 284 & 254 & 68 \\
\hline F statistic & $\begin{array}{c}43.63^{* * *} \\
(\mathrm{df}=3 ; 280)\end{array}$ & $\begin{array}{c}429.6^{* * *} \\
(\mathrm{df}=4 ; 249)\end{array}$ & $\begin{array}{c}78.98^{* * *} \\
(\mathrm{df}=1 ; 66)\end{array}$ \\
\hline Coefficients & $3.26^{* * *}$ & $2.99^{* * *}$ & $3.3^{* * *}$ \\
\hline Intercept & $-0.1518^{* * *}$ & $-0.0657^{* * *}$ & - \\
\hline $\ln \left\langle Q_{\text {Total }}\right\rangle$ & - & $0.0018^{* * *}$ & $0.0011^{* * *}$ \\
\hline Specific Conductance $(\mu \mathrm{S} / \mathrm{cm})$ & - & - & - \\
\hline $\begin{array}{l}\text { Rainfall, maximum in the } \\
\text { previous two weeks (inches) }\end{array}$ & $0.0477^{* * *}$ & $0.0238^{* * *}$ & - \\
\hline $\begin{array}{l}\text { Snow depth, maximum in the } \\
\text { previous two weeks (inches) }\end{array}$ & - & $0.0311^{* *}$ & - \\
\hline Season & $0.011^{* *}$ & - & - \\
\hline $\begin{array}{l}\text { No. of days below freezing in } \\
\text { the previous two weeks }\end{array}$ & & & 0.87 \\
\hline Model performance metrics & 0.31 & 0.10 & 0.053 \\
\hline Adjusted $R^{2}$ & 0.24 & & \\
\hline RMSE & &
\end{tabular}




\begin{tabular}{|l|c|c|c|}
\hline PBIAS & $-2.9 \%$ & $0.6 \%$ & $0.7 \%$ \\
\hline BIC & 30.37 & -398.14 & -192.39 \\
\hline LOOCV prediction error & 0.195 & 0.086 & 0.041 \\
\hline
\end{tabular}

${ }^{*} P<0.05,{ }^{* *} P<0.01,{ }^{* * *} P<0.001$.

Daily Timeseries of Sodium Mass Load and Concentration. Synthetic time series of sodium concentration (generated using the top-ranked and validated MLR models described above) were combined with daily flow measurements at ST10, ST45, and UOSA to generate daily realizations (from 2010 through 2018) of sodium mass load and concentration in flows from the three putative sources evaluated in this study_ Occoquan River Watershed, Bull Run Watershed, and UOSA water reclamation facility (see Methods). When these daily realizations are aggregated to annual averages, the results are in line with previous reports for regions that experience seasonal frozen precipitation; namely, annual mass loading of sodium to the Occoquan Reservoir is dominated by the two watershed sources, not by UOSA (Figure 2a). Consistent with Figure 1b, however, the annualized sodium concentration in UOSA's discharge is well above EPA's lower threshold for taste $(30 \mathrm{mg} / \mathrm{L})$, and $>1.5$ and $>4.5$ times above the annualized sodium concentration in flow from the Bull Run and the Occoquan River watersheds, respectively (Figure 2b).

These annualized results could be interpreted to mean that UOSA contributes a relatively minor portion of sodium mass loading to the Occoquan Reservoir. However, the story is more nuanced when evaluated on a day-by-day basis (Figure 3). During extended periods of reduced precipitation, sodium mass load from UOSA frequently exceeds mass loads from either the Occoquan River or Bull Run watersheds (see four vertical yellow stripes, Figure 3b). During wet weather, on the other hand, sodium mass loads from the two watersheds consistently exceed those from UOSA, often by $>200$-fold (note that the sodium mass load axis in Figure $3 \mathrm{~b}$ is logarithmic). Spikes in wet weather sodium mass loading from the two watersheds dominate the 

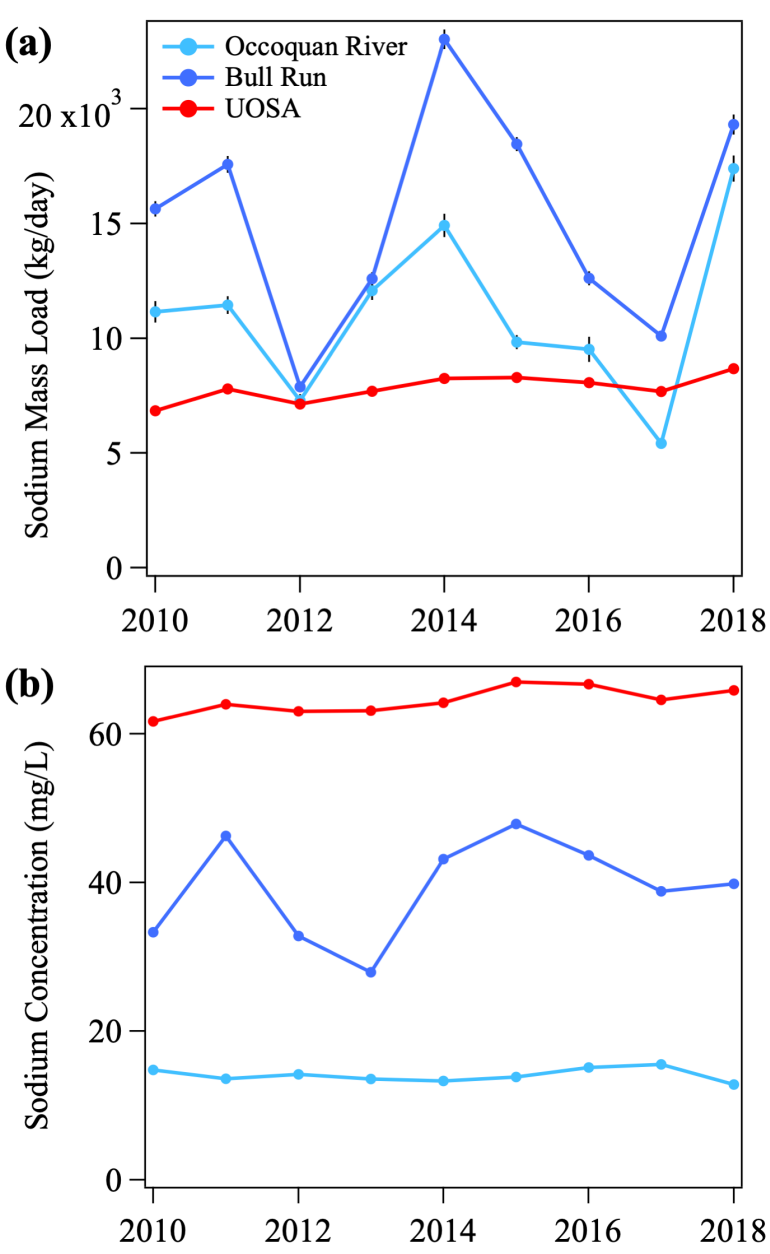

Figure 2. (a) Annualized sodium mass loads and (b) sodium concentration from Occoquan River, Bull Run and UOSA water reclamation facility. annual load estimates, giving the potentially misleading impression that UOSA is a minor contributor to sodium in the reservoir (compare with Figure 2a). These daily and annual sodium mass load estimates should be relatively robust to uncertainty in the MLRgenerated synthetic sodium concentration timeseries, because most of the mass loading variance $\left(\mathrm{R}^{2}=66 \%, 91 \%\right.$ and $82 \%$ for Occoquan River watershed, Bull Run watershed and UOSA, respectively) is attributable to measured daily average flow at each station.

Consistent with the annualized results (Figure 2b), on a day-to-day basis the sodium concentration in UOSA's effluent is nearly always higher than the sodium concentration in outflows from the Occoquan River and Bull Run watersheds (Figure 3d). Sodium concentration in outflow from the Bull Run watershed is also almost always higher than in outflow from the Occoquan River watershed, consistent with the latter's higher imperviousness (Table 2).

Table 2. Characteristics of the two watersheds.

\begin{tabular}{|c|c|c|}
\hline & Occoquan River Watershed & Bull Run Watershed \\
\hline Station & ST10 & ST45 \\
\hline Drainage Area (square $\mathrm{km})$ & 890 & 390 \\
\hline Impervious Surface Cover $(\%)$ & 4.0 & 11 \\
\hline
\end{tabular}

Source: 2010 land use data for the Occoquan Watershed from Occoquan Watershed Monitoring Laboratory’s Hydrologic Simulation Program FORTRAN (HSPF) model [109]. 


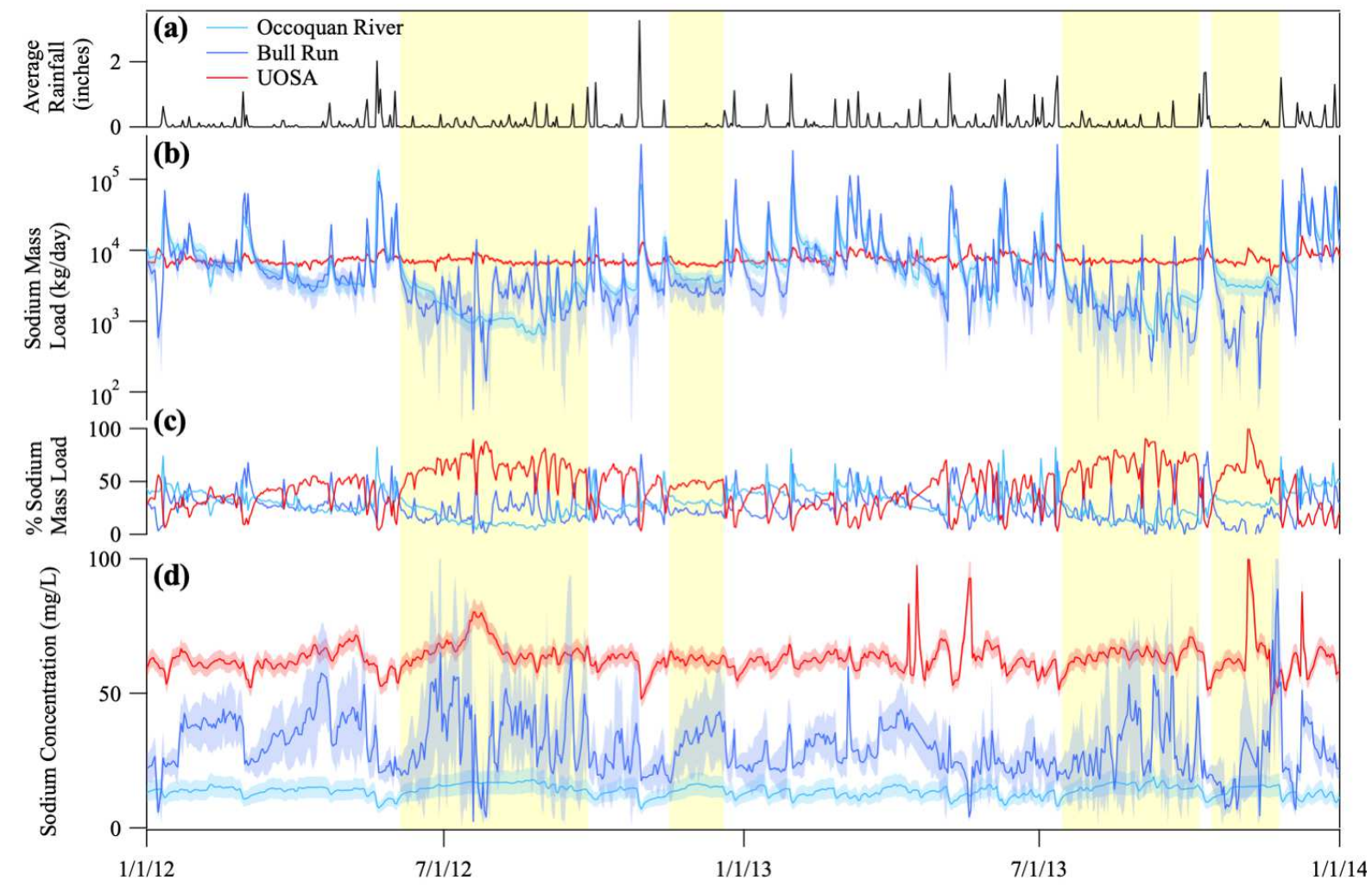

Figure 3. (a) Daily average rainfall in the watershed, (b) daily realizations of sodium mass load, (c) percentage of total sodium mass load and (d) daily realizations of sodium concentration from the Occoquan River, Bull Run and UOSA respectively for an illustrative two-year period (2012-2013).

Influence of Weather on Sodium Mass Loading. Application of a copula-based conditional probability analysis to daily realizations of sodium mass load for the period 2010 to 2018 (see Methods) confirms that UOSA's discharge dominates the sodium mass load entering the reservoir from the Occoquan River and Bull Run during dry and median weather conditions (Figure 4). UOSA's percentage contribution to sodium mass loading varies from 60 to $80 \%$ during dry conditions (corresponding to cumulative flow from the Occoquan River and Bull Run of $\left\langle Q_{\text {Total }}\right\rangle=90$ cubic feet per second (cfs) $), 30$ to $50 \%$ during median conditions $\left(\left\langle Q_{\text {Total }}\right\rangle=244\right.$ cfs), and 5 to $25 \%$ during wet conditions $\left(\left\langle Q_{\text {Total }}\right\rangle=1095 \mathrm{cfs}\right)$. The Occoquan River and Bull Run watersheds exhibit the opposite pattern, contributing a greater percentage of the overall sodium load during wet weather periods. During wet weather, sodium mass loading from the Bull Run 
Low Flow $(90 \mathrm{cfs})$

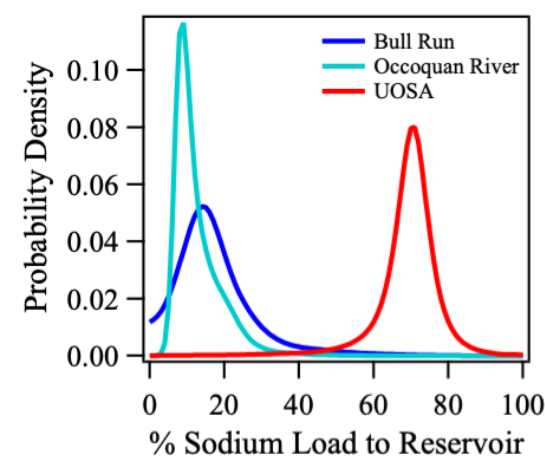

Median Flow (244 cfs)

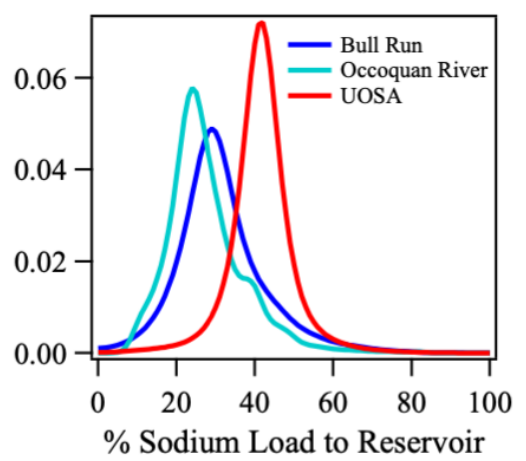

High Flow (1095 cfs)

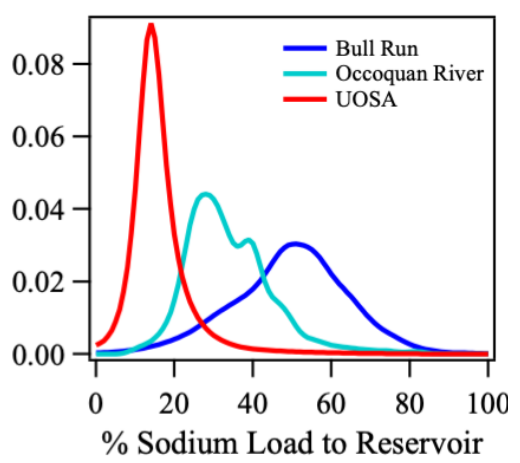

Figure 4. Probability density functions (PDFs) of sodium mass loads conditioned on low, medium and high flow into the reservoir (columns 1,2 and 3 respectively; cfs = cubic feet per second). The salient feature of each curve is the range of values on the horizontal axis for which there is non-zero probability density. The peak height of each curve is determined by the unit area of the PDF.

watershed is, on average, higher than sodium mass loading from the Occoquan River watershed, consistent with the land use data in Table 2.

Sources of Wastewater Salts. The results presented above support our hypothesis that, when evaluated on a daily basis, discharge from wastewater reclamation facilities can be a significant component of the freshwater sodium budget even in areas, like the mid-Atlantic US, where deicers are a well-documented cause of inland freshwater salinization $[9,16-20]$. Where is the sodium in UOSA's discharge coming from? UOSA's sewage collection system serves as a conduit through which sodium from myriad sources (watershed deicers, water treatment processes, household products, commercial and industrial discharges, and wastewater treatment) are focused into a single point source discharge (Figure 5a). Based on data provided by the utility we estimate that, on an annual average, $46.5 \%$ of the daily sodium mass load from UOSA (7600 $\pm 590 \mathrm{~kg} \mathrm{day}^{-1}$ ) is partitioned between chemicals used in water and wastewater treatment (for $\mathrm{pH}$ adjustment, chlorination, dechlorination, and odor control), a single permitted discharge from a microfabrication facility, and human excretion; the latter was estimated by multiplying UOSA's service population $(351,906)$ [68] by a mean excretion rate of $3.608 \mathrm{~g} \mathrm{Na}^{+}$day${ }^{-1}$ [79] (Figure $5 b)$. The source of the remaining $53.5 \%$ is unknown, but presumably includes contributions from 
(a)

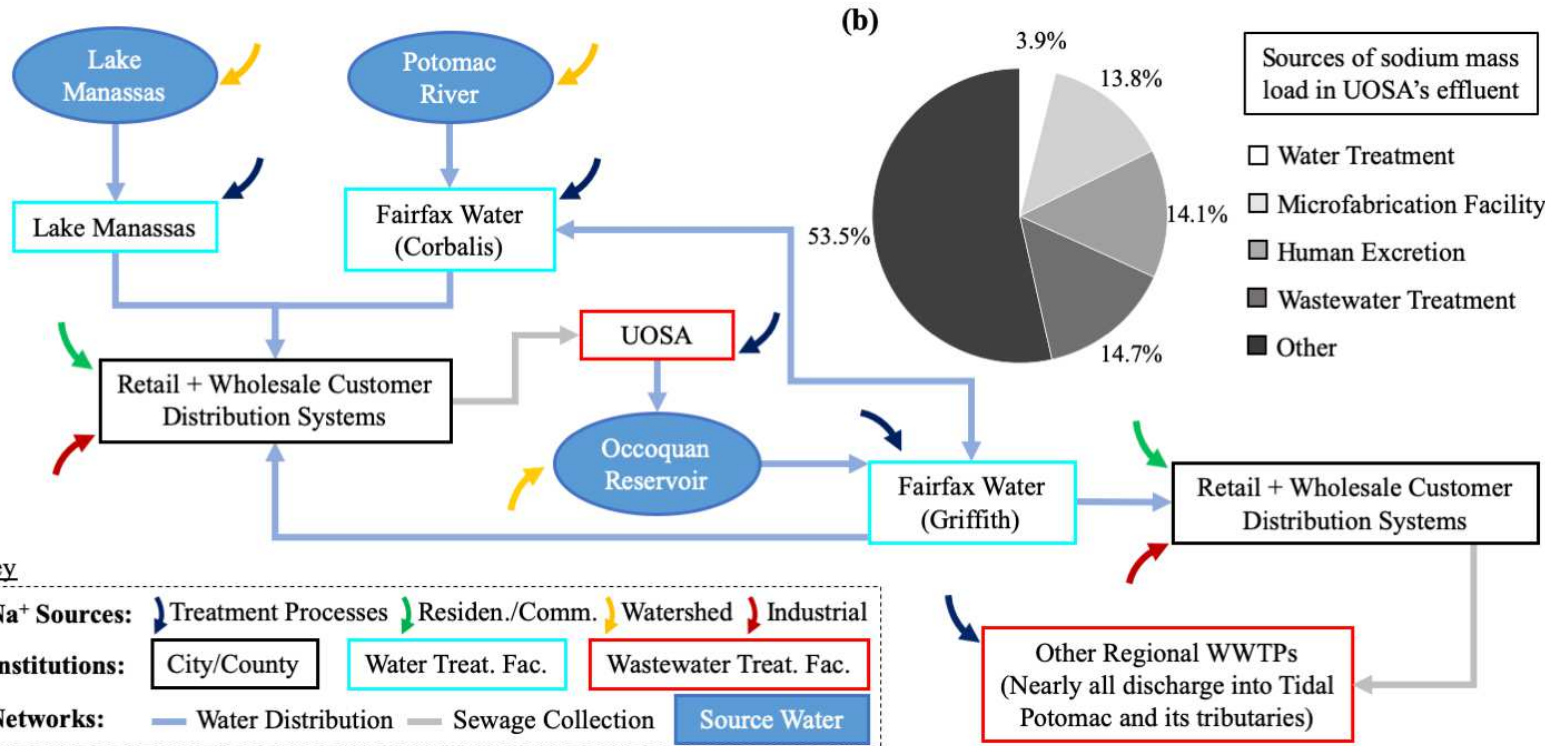

Figure 5. (a) Schematic representation of the drinking water and sewage collection network for the Occoquan watershed and surrounding area. Under normal conditions, the portion of the sewage network draining to UOSA receives water from the Fairfax Water's Corbalis water treatment plant, although some water from Fairfax Water's Griffith water treatment plant may also contribute to UOSA's inflow (forming a system-scale semi-closed loop for the circulation of sodium through the Occoquan Reservoir). (b) Source breakdown for the annual sodium load in UOSA's reclaimed water.

the down-drain disposal of sodium-containing drinking water from Lake Manassas, the Potomac River and the Occoquan Reservoir, as well as sodium-containing household products that eventually end up in the sanitary sewer system.

Generalizable Lessons. Given these results for the Occoquan reservoir, how can the potential conflict raised earlier-between reducing the FSS and promoting water security through IPR — be addressed? One possible conceptual framework, borrowed from soft-path approaches for enhancing human water security [80,81], focuses on a variety of approaches at various scales for improving what we propose to call "salt productivity"; i.e., the goods and services produced per unit of salt discharged to inland freshwaters. As applied to sodium, there are at least four ways in which salt productivity could be improved: (1) reduce watershed sources of sodium that enter the water supply (such as from deicer use); (2) enforce more stringent pretreatment requirements on industrial and commercial dischargers; (3) switch to low-sodium 
water and wastewater treatment methods; and (4) encourage households in the sewershed to adopt low-sodium products. We consider each of these in turn.

Because the sewage collection and potable water supply distribution systems are inextricably linked (e.g., Figure 5a), factors that contribute salt to the former ultimately contribute salt to the latter as well. As mentioned earlier, many different sources (apart from treated wastewater) contribute salt to inland freshwaters, most notably deicer use in northern climates but also untreated sewage (e.g., from failing septic systems [82]) and erosion of civil infrastructure (e.g., pavement [83]). With respect to deicers, their use on roadways can be curtailed without a reduction in public safety (e.g., through precision deicer application [84]). However, interventions at the watershed scale raise many questions across various domains, including human behavior (e.g., how do we induce residents to be more conservative about their use of deicers on parking lots and driveways, and what is the "right amount" of deicer they should be using?); hydrology (what are the hydrologic pathways by which salt moves through watersheds, and what are their timescales?); ecology (how do the changing concentrations and compositions of salinized waters alter biological communities and ecosystem processes?); and engineering design (are we unintentionally creating legacy salt pollution by adopting stormwater best management practices that transfer road salts to groundwater?). In such complex sociohydrological-ecological systems, well intended interventions can have adverse consequences and so-called "aggregation effects" in which "desirable outcomes at a larger scale conceal inequalities and, as such, distributional injustices at the local scale" [85]. For example, deicer use might be reduced by lowering expectations for clean roads and public transportation during winter storms, but such actions could also limit access to free and subsidized school breakfast and lunch programs for low-income children and thereby exacerbate child hunger [86]. 
Sodium reductions can also be achieved by the imposition of more stringent pretreatment requirements on commercial and industrial dischargers, although this will inevitably raise questions regarding potential economic trade-offs. For example, nearly $14 \%$ of the annual sodium load discharged by UOSA can be traced to a single chip fabrication facility (Figure 5b) - a facility that is currently undergoing a major expansion that could add up to 1000 highpaying jobs to the local economy [87].

Salt productivity can also be improved through changes in centralized water and wastewater treatment practices. Chlorine is a cost-effective and well-established method for destroying viruses, bacteria and protozoa, including those responsible for waterborne human disease [88]. Wastewater treatment plants that use chlorine to disinfect their water must also dechlorinate to prevent harm to downstream aquatic life. Dechlorination is typically achieved through the addition of sulfur dioxide or sulfite salts, including sodium sulfite, sodium bisulfite, or sodium metabisulfite [89] thereby increasing the sodium content of the water [90].

Dechlorination dosages depend on the compound used; e.g., sodium sulfite, sodium bisulfite, and

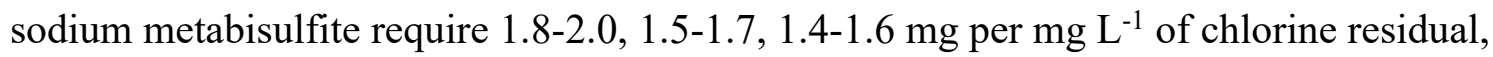
respectively [91]. Therefore, judicious choice of a dechlorinating agent or the use of alternative disinfectants (e.g., ultraviolet (UV) light) can help reduce sodium mass loading from wastewater treatment. Likewise, there are multiple steps in the drinking water treatment process where sodium can be introduced (Table 3). A drinking water facility looking to decrease sodium use should begin by identifying which of their processes contribute sodium and what alternative chemicals or processes might be adopted. As with the chip manufacturing example above, however, economic constraints and a risk averse culture among public sector utilities [92-94] may limit what can be achieved in practice. 
Table 3. Steps during the drinking water treatment process that introduce sodium and alternative low-sodium or sodium-free methods or compounds.

\begin{tabular}{|c|c|c|c|}
\hline $\begin{array}{l}\text { Treatment } \\
\text { Process }\end{array}$ & $\begin{array}{c}\text { Sodium } \\
\text { Introducing } \\
\text { Compound(s) }\end{array}$ & Sodium-free Alternatives & Reference \\
\hline Softening & $\begin{array}{l}\text { Soda ash (sodium } \\
\text { carbonate) or by ion- } \\
\text { exchange processes }\end{array}$ & $\begin{array}{l}\text { Electrically induced } \\
\text { precipitation, template } \\
\text { assisted crystallization, } \\
\text { magnetic water treatment, and } \\
\text { electrically induced } \\
\text { precipitation or capacitive } \\
\text { deionization, polyphosphate, } \\
\text { or lower water heater } \\
\text { temperature set points }\end{array}$ & $\begin{array}{l}\text { Shammas and } \\
\text { Wang, 2016 [110]; } \\
\text { AWWA, 1999 } \\
\text { [111]; Wiest et al., } \\
\text { 2011 [112]; Wang } \\
\text { et al., 2017 [113]; } \\
\text { Richards et al., } \\
\text { 2018 [114] }\end{array}$ \\
\hline $\begin{array}{l}\text { Increasing } \mathrm{pH} \\
\text { for corrosion } \\
\text { control, or to } \\
\text { counter any acid } \\
\text { producing } \\
\text { reactions }\end{array}$ & $\begin{array}{l}\text { Soda Ash }\left(\mathrm{Na}_{2} \mathrm{CO}_{3}\right) \text {, } \\
\text { Sodium bicarbonate } \\
(\mathrm{NaHCO}) \text { or } \\
\text { sodium hydroxide } \\
(\mathrm{NaOH})\end{array}$ & $\begin{array}{l}\text { Use potassium or calcium } \\
\text { hydroxide (lime) to increase } \\
\mathrm{pH} \text {, or reduce/eliminate the } \\
\text { acid producing reactions (i.e., } \\
\text { coagulation) by using } \\
\text { alternative such as } \\
\text { membranes }\end{array}$ & $\begin{array}{l}\text { Rehring et al., } \\
1996 \text { [115]; } \\
\text { Shammas and } \\
\text { Wang, } 2016 \text { [110] }\end{array}$ \\
\hline $\begin{array}{l}\text { Chlorine gas } \\
\text { generation }\end{array}$ & $\begin{array}{l}\mathrm{NaCl} \text { brine can leak } \\
\text { into potable water if } \\
\mathrm{Cl}_{2} \text { gas is generated } \\
\text { onsite }\end{array}$ & Stop brine leaks & $\begin{array}{l}\text { Nguyen et al., } \\
2010 \text { [116] }\end{array}$ \\
\hline Anion Exchange & $\begin{array}{l}\mathrm{NaCl} \text { regeneration of } \\
\text { columns used for } \\
\text { nitrate, arsenic, } \\
\text { uranium removal }\end{array}$ & $\begin{array}{l}\text { Adsorption, biological } \\
\text { treatment, coagulation as } \\
\text { appropriate. }\end{array}$ & $\begin{array}{l}\text { Nguyen et al., } \\
2010 \text { [116] }\end{array}$ \\
\hline Disinfection & $\begin{array}{l}\text { Sodium hypochlorite } \\
\text { or sodium chlorite or } \\
\text { chloramine }\end{array}$ & $\begin{array}{l}\mathrm{Cl}_{2} \text { gas. UV, ozone, } \\
\text { membrane filtration, reverse } \\
\text { osmosis can reduce doses }\end{array}$ & $\begin{array}{l}\text { Dotson et al., } 2012 \\
\text { [117]; } \\
\text { Collivignarelli et } \\
\text { al., } 2017 \text { [118] }\end{array}$ \\
\hline Fluoridation & $\begin{array}{l}\text { Sodium fluoride, } \\
\text { sodium fluorosilicate }\end{array}$ & Hexafluorosilicic acid & $\begin{array}{l}\text { AWWA, } 1999 \\
{[111]}\end{array}$ \\
\hline $\begin{array}{l}\text { Corrosion } \\
\text { inhibitor }\end{array}$ & $\begin{array}{l}\text { Sodium silicates, } \\
\text { sodium phosphates }\end{array}$ & $\begin{array}{l}\text { Replace the antiquated } \\
\text { infrastructure at risk of } \\
\text { corrosion, or use lime } \\
\text { columns to adjust pH- } \\
\text { alkalinity }\end{array}$ & $\begin{array}{l}\text { Tang et al., } 2018 \\
\text { [119]; Benjamin et } \\
\text { al., 1992 [120] }\end{array}$ \\
\hline Coagulation & $\begin{array}{l}\text { Sodium aluminate, } \\
\text { sodium alginate } \\
\text { (coagulant aid) }\end{array}$ & $\begin{array}{l}\text { Aluminum sulfate, ferric } \\
\text { sulfate, ferrous sulfate }\end{array}$ & $\begin{array}{l}\text { Sahu and } \\
\text { Chaudhari, } 2013 \\
\text { [121], AWWA and } \\
\text { ASCE, 1990 [122] }\end{array}$ \\
\hline
\end{tabular}


Finally, improvements in salt productivity are also possible at the household scale. Most research on household product ionic composition has been carried out in countries interested in greywater recycling as a water conservation strategy [70]. For example, in 2008 a comprehensive study of sodium mass loads from household products in Melbourne, Australia reported that [71]: (1) laundry and dishwashing products contribute orders of magnitude more to sodium mass loads than do other household products; (2) median sodium mass loads from household products are 58-300\% higher than those from human excretion; (3) mass loads of sodium can vary significantly across product brands, which leads to high variability in the salinity of household wastewater streams; and (4) product switching has the potential to significantly reduce sodium mass loading to the sewershed. Assuming human excretion accounts for about $14 \%$ of the UOSA sodium mass loads (Figure 5b), these Australian results suggest that household products could account for another 10 to $51 \%$; notably, the upper limit would come close to closing UOSA's annual sodium mass balance. Educational and social marketing campaigns aimed at informing consumers and manufacturers about the FSS, and fostering product and behavioral changes, could ultimately reduce salt loading from common household products such as detergents [95].

In summary, addressing the contribution of IPR to sodium pollution at our field site, and the FSS more generally, will entail implementing a combination of the above approaches, tailored to the local political, social and environmental context.

\section{Methods}

Historical Monitoring Data. To characterize the relative sodium contributions of the Bull Run watershed, the Occoquan River watershed, and UOSA's discharge in the Occoquan Reservoir, we utilized data from a long-term ( $>25$ year) sampling program that was originally established to monitor UOSA's impact on water quality in the reservoir [66]. We focused specifically on a time period, 2006 through 2018, during which discrete surface water samples 
were collected weekly or semi-weekly from the Occoquan River and the Bull Run monitoring stations (ST10 and ST45, N=395 and 338, blue circles, Figure 1a) and analyzed for a suite of water quality parameters including sodium concentration. Continuous measurements $(f=1$ hour $\left.^{-1}\right)$ of specific conductance $(\mathrm{N}=106,708$ at ST45) and flow $(\mathrm{N}=160,446$ and 170,179 at ST10 and ST45, respectively) were also available during this time frame. Daily average measurements of discharge from UOSA were provided by the utility for the period 2010 to $2018(\mathrm{~N}=2,941)$, along with measurements of specific conductance $(\mathrm{N}=2,943)$ and sporadic measurements of sodium concentration $(\mathrm{N}=68)$ on daily flow-weighted composite samples of effluent discharged to their final detention reservoir.

Daily Average Timeseries of Sodium Concentration and Mass Loads. From the monitoring data described above we set out to evaluate the relative contribution of three key sources - the Occoquan River watershed, the Bull Run watershed, and UOSA - to sodium mass load (mass per time) and concentration (mass per volume) entering the Occoquan Reservoir under various weather and environmental conditions. Several limitations with the monitoring data had to be overcome (c.f., [47]): (1) flow and sodium concentration measurements at ST45 reflect the combined inputs from the Bull Run Watershed and the UOSA treatment plant; (2) at ST10 and ST45 sodium concentrations were measured on grab samples, whereas sodium concentrations reported by UOSA were measured on daily flow-weighted composites of their final effluent; (3) the sampling schedules at ST10 and ST45 were asynchronous (i.e., grab samples were collected at different times on any given day, or on different days); and (4) while sodium measurements at ST10 and ST45 were collected every other week for the entirety of the study period (2010 to 2018), sodium measurements on UOSA's composite samples were sporadic and infrequent (see Figure S1, Supplementary Materials). 
To address these challenges, for the period 2010 to 2018 (for which all of the required data resources were available) we constructed synthetic daily time series of average sodium mass load and concentration at the three monitoring locations as follows: (tep 1) at each monitoring station a multiple linear regression (MLR) model of log-transformed sodium concentration (dependent variable) was prepared (glmulti package in R [96]) by adopting, based on stakeholder recommendations, the following set of potential environmental covariates (independent variables): (a) hourly stream flow (ST45 and ST10) or daily average final flow discharged to Bull Run (UOSA), (b) maximum daily rainfall in the preceding two weeks, (c) maximum daily snow depth in the preceding two weeks, (d) number of days below freezing in the preceding two weeks, (e) season (as represented by sine and cosine functions with annual periodicity), and (f) either hourly in situ measurements of specific conductance (ST45) or measurements of specific conductance on daily flow weighted composites (UOSA). For model validation we used the hold out method at ST10 and ST45 [97] and leave one out cross-validation root mean square error (LOOCV-RMSE ) at UOSA (see Supplemental Information for details); (Step 2) the population of MLR models generated for each monitoring station in Step 1 were ranked according to Bayesian Information Criterion (BIC) to identify the most parsimonious model, taking into account the tradeoff between model fit and model complexity $[98,99]$. If the top-ranked models for a given station were within two BIC units, they were further ranked by LOOCV-RMSE [100]; (Step 3) the final top-ranked MLR model for each station from Step 2 was then used to generate an eight-year (2010 to 2018) synthetic timeseries of hourly (ST10 and ST45) or daily (UOSA) sodium concentration; and (Step 4) the synthetic sodium concentration time series from Step 3 were combined with hourly (ST10 and ST45) or daily (UOSA) flow measurements at each station, and then aggregated to daily and annual sodium concentration and mass load using 
the aggregateSolute command in the USGS software package Loadflex (for error propagation we adopted the default data correlation structure, which adopts a unit correlation if two samples are collected on the same calendar date, and zero correlation otherwise [101]). The final result was three fully aligned eight-year synthetic timeseries of daily and annual average sodium mass load and concentration (denoted here by the symbols $\langle L\rangle$ and $\langle C\rangle$, respectively) and associated estimates of error at each of the three monitoring stations. As noted above, ST45 receives water and sodium from both the Bull Run Watershed and the UOSA water reclamation facility. The contribution of the Bull Run Watershed to sodium concentration and mass load was therefore isolated by mass balance where $\langle Q\rangle$ denotes daily average flow measurements and the subscript "BR" refers to the Bull Run Watershed:

$$
\begin{aligned}
& \left\langle C_{\mathrm{BR}}\right\rangle=\frac{\left\langle L_{\mathrm{ST} 45}\right\rangle-\left\langle L_{\mathrm{UOSA}}\right\rangle}{\left\langle Q_{\mathrm{ST} 45}\right\rangle-\left\langle Q_{\text {UOSA }}\right\rangle} \\
& \left\langle L_{\mathrm{BR}}\right\rangle=\left\langle L_{\mathrm{ST} 45}\right\rangle-\left\langle L_{\text {UOSA }}\right\rangle
\end{aligned}
$$

From these synthetic timeseries we constructed a daily timeseries for the percent contribution of the Occoquan River Watershed ("OccRiv"), Bull Run Watershed ("BullRun"), and UOSA discharge ("UOSA")) to the total sodium mass entering the reservoir from the Occoquan River and Bull Run (which, as noted earlier, contributes $95 \%$ of freshwater flow into the reservoir):

$$
\begin{aligned}
& \operatorname{cLoad}_{\text {OccRiv }}=\frac{\left\langle L_{\text {ST } 10}\right\rangle}{\left\langle L_{\text {ST } 10}\right\rangle+\left\langle L_{\text {ST } 45}\right\rangle} \\
& \text { \%Load }_{\text {BullRun }}=\frac{\left\langle L_{\text {BR }}\right\rangle}{\left\langle L_{\text {ST10 }}\right\rangle+\left\langle L_{\text {ST } 45}\right\rangle} \\
& \text { \%Load }_{\text {UOSA }}=\frac{\left\langle L_{\text {UOSA }}\right\rangle}{\left\langle L_{\text {ST } 10}\right\rangle+\left\langle L_{\text {ST } 45}\right\rangle}
\end{aligned}
$$


Construction of Bivariate Distributions and Conditional Probabilities. Equations (2a) (2c) provide daily realizations for the relative contribution of each source to sodium mass discharged to the reservoir from the Occoquan River and Bull Run. How are these realizations modulated by local weather conditions? To answer this question, we adopted the cumulative daily discharge of water flowing into the reservoir from the Occoquan River and Bull Run as a proxy of local weather conditions: $\left\langle Q_{\text {Tоtal }}\right\rangle=\left\langle Q_{\text {ST10 }}\right\rangle+\left\langle Q_{\text {ST45 }}\right\rangle$. Marginal probability distributions of percent sodium mass load from equations (2a)-(2c) $\left(\%_{L_{0} a_{\text {occkiv }}}, \%\right.$ Load $_{\text {BullRun }}, \%$ Load $\left._{\text {UosA }}\right)$ and log-transformed values of cumulative streamflow from the Occoquan River and Bull Run ( $\left.\ln \left\langle Q_{\text {Total }}\right\rangle\right)$ were then joined by a copula to yield three bivariate cumulative distribution functions (CDFs) of the form, $F_{L Q}(\ell, q)=C\left[F_{L}(\ell), F_{Q}(q)\right]$, where $L$ and $Q$ are random variables for the percent sodium mass load from a particular source and cumulative discharge from the Occoquan River and Bull Run, respectively, $\ell$ and $q$ are specific realizations of these random variables, and $C$ is the CDF of the copula function. The copula was selected based on BIC ranking [102] of the Plackett and Archimedean copula families [103] optimized to our daily timeseries of percent mass load (from equations (2a) - (2c)) and measured daily cumulative discharge from the Occoquan River and Bull Run using the MATLAB software package, MvCAT [104]. The probability density function (PDF) of percent sodium mass load from each of the three sources conditioned on a specific cumulative discharge was then calculated as follows [103]:

$f_{L \mid Q}(\ell \mid q)=c\left[F_{L}(\ell), F_{Q}(q)\right] f_{L}(\ell)$

Here, the function $c$ is the PDF form of the copula and $f_{L}(\ell)$ is the marginal distribution for the percent of sodium mass load to the Occoquan Reservoir from a particular source. We focused on three conditioning events corresponding to low $\left(10^{\text {th }}\right.$ percentile $)$, medium $\left(50^{\text {th }}\right.$ percentile $)$, and 
high $\left(90^{\text {th }}\right.$ percentile $)$ cumulative discharge $\left(\left\langle Q_{\text {Total }}\right\rangle=90 \mathrm{ft}^{3} \mathrm{~s}^{-1}, 244 \mathrm{ft}^{3} \mathrm{~s}^{-1}\right.$, and $1095 \mathrm{ft}^{3} \mathrm{~s}^{-1}$, respectively). These three conditioning events represent dry, average, and wet weather conditions, respectively.

Stationarity. The time-series data used for the copula analysis and to generate the MLR models were tested for stationarity (tseries package in R [105]) using the Augmented DickeyFuller (ADF) test [106], Phillips-Perron (PP) test [107] and the Kwiatkowski-Phillips-SchmidtShin (KPSS) test [108]. These test statistics indicate, for the time period over which the MLR and copula analyses were conducted (2010-2018), measured sodium concentration and all independent variables are stationary (see Table S2 and discussion in Supplemental Information).

\section{Acknowledgments and Data}

The authors declare no conflicts of interest. All data used in this study are publicly available [127]. Funding was provided by Virginia Tech's Charles E. Via, Jr. Department of Civil and Environmental Engineering and a US National Science Foundation Engineering Research Center Planning Grant to SBG (award 1840504). SVB and SBG conceived and drafted the article. EAP, MAR, AG, PV, AM, ME, GP, NS, and SC contributed text and analysis. All co-authors contributed edits. The authors thank the Upper Occoquan Service Authority-in particular, Bob Angelotti and Mishelle Noble-Blair-for providing critical data and guidance, and participants in the Occoquan Watershed Monitoring Lab's Freshwater Salinization Workshop held on January 14, 2020. Supporting Information includes figures and information on MLR validation and stationarity tests. 


\section{$\underline{\text { References }}$}

[1] Cañedo-Argüelles, M., Kefford, B., \& Schäfer, R. Salt in freshwaters: causes, effects and prospects introduction to the theme issue. Philosophical transactions of the Royal Society of London. Series B, Biological sciences 37, 20180002 (2018).

[2] Williams, W.D. Anthropogenic salinization of inland waters. Hydrobiologia 466, 329-337 (2001). [3] Rengasamy, P. World salinization with emphasis on Australia. J. Experimental Botany 57, 1017-1023 (2006).

[4] Dugan, H.A. et al. Salting our freshwater lakes. Proc. Nat. Acad. Sci. U.S.A. 114, 4453-4458 (2016). [5] Kaushal, S.S. et al. Increased salinization of fresh water in the northeastern U.S. Proc. Nat. Acad. of Sci. U.S.A. 102, 13517-13520 (2005).

[6] Kaushal, S.S., Likens, G.E., Jaworski, N., Pace, M.L. Rising stream and river temperatures in the United States. Front. Ecol. Environ. 8, 461-466 (2010).

[7] Kaushal S.S. et al. Increased river alkalinization in the Eastern U.S. Environ. Sci. Technol. 47, 1030210311 (2013).

[8] Kaushal, S.S. et al. Freshwater salinization syndrome on a continental scale. Proc. Nat. Acad. of Sci. U.S.A. 115, E574-E583 (2018).

[9] Bird, D.L., Groffman, P.M., Salice, C.J., Moore, J. Steady-state land cover but non-steady-state major ion chemistry in urban streams. Environ. Sci. Technol. 52, 13015-13026 (2018).

[10] Godwin, K.S., Hafner, S.D., Buff, M.F. Long-Term Trends in Sodium and Chloride in the Mohawk River, New York: The Effect of Fifty Years of Road-Salt Application. Environ. Pollut. 124, 273-281 (2003).

[11] Rosfjord, C.H., Webster, K.E., Kahl, J.S., Norton, S.A., Fernandez, I.J., Herlihy, A.T.

Anthropogenically Driven Changes in Chloride Complicate Interpretation of Base Cation Trend in Lakes Recovering from Acid Deposition. Environ. Sci. Technol. 41, 7688-7693 (2007).

[12] Kelly, V.R. et al. Long-term sodium chloride retention in a rural watershed: legacy effects of road salt on streamwater concentration. Environ. Sci. Technol. 42, 410-415 (2008).

[13] Olson, J.R. Predicting combined effects of land use and climate change on river and stream salinity. Philosophical Transactions of the Royal Society B: Biological Sciences 374, 20180005 (2019).

[14] Corsi, S.R., De Cicco, L.A., Lutz, M.A., Hirsch, R.M. River chloride trends in snow-affected urban watersheds: increasing concentrations outpace urban growth rate and are common among all seasons. Sci. Total Environ. 608, 488-494 (2015).

[15] Kaushal S.S. et al. Novel 'Chemical Cocktails' in Inland Waters Are a Consequence of the Freshwater Salinization Syndrome.' Philosophical Transactions of the Royal Society B: Biological Sciences 374, 20180017 (2019).

[16] Moore, J., Fanelli, R.M., Sekellick, A.J. High-Frequency Data Reveal Deicing Salts Drive Elevated Specific Conductance and Chloride along with Pervasive and Frequent Exceedances of the U.S.

Environmental Protection Agency Aquatic Life Criteria for Chloride in Urban Streams. Environ. Sci. Technol., in press (doi: 10.1021/acs.est.9b04316) (2020).

[17] Lofgren, S. The chemical effects of deicing salt on soil and stream water of five catchments in southeast Sweden. Water Air Soil Pollut. 130, 863-868 (2001).

[18] Daley, M.L., Potter, J.D., McDowell, W.H. Salinization of urbanizing New Hampshire streams and groundwater: Effects of road salt and hydrologic variability. J. N. Am. Benthol. Soc. 28, 929-940 (2009).

[19] Cooper, C.A., Mayer, P.M., Faulkner, B.R. Effects of road salts on groundwater and surface water dynamics of sodium and chloride in an urban restored stream. Biogeochemistry 121, 149-166 (2014).

[20] Snodgrass, J.W. et al. Influence of modern stormwater management practices on transport of road salt to surface waters. Environ. Sci. Technol. 51, 4165-4172 (2017).

[21] Steele, M.K., Aitkenhead-Peterson, J.A. Long-term sodium and chloride surface water exports from the Dallas/Fort Worth region. Sci. Total Environ. 409, 3021-3032 (2011). 
[22] Darwish, T., Atallah, T., Moujabber, M., Khatib, N. Salinity evolution and crop response to secondary soil salinity in two agro-climatic zones in Lebanon. Agricultural Water Management 78, 152164 (2005).

[23] Davies, P.J., Wright, I.A., Jonasson, O.J., Findlay, S.J. Impact of concrete and PVC pipes on urban water chemistry. Urban Water J. 7, 233-241 (2010).

[24] Wright, I.A., Davies, p.J., Jonasson, O.J., Findlay, S.J. A new type of water pollution: concrete drainage infrastructure and geochemical contamination of urban waters. Marine and Freshwater Res. 62, 1355-1361 (2011).

[25] Moore, J., Bird, D., Dobbis, S., Woodward, G. Nonpoint Source Contributions Drive Elevated Major Ion and Dissolved Inorganic Carbon Concentrations in Urban Watersheds. Environmental Science \& Technology Letters 4, 198-204 (2017).

[26] Tippler, C., Wright, I.A., Davies, P.J., Hanlon, A. The influence of concrete on the geochemical qualities of urban streams. Marine and Freshwater Res. 65, 2009 (2014).

[27] McLennan, S.M. Weathering and global denudation. J. Geol. 101, 295-303 (1993).

[28] Wilkinson, B.H. Humans as geologic agents: a deep-time perspective. Geology 33, 161-164 (2005).

[29] Schuler, M.S. et al. Regulations are needed to protect freshwater ecosystems from salinization.

Philosophical Transactions of the Royal Society B: Biological Sciences 374, 20180019 (2019).

[30] Haq, S., Kaushal, S.S., Duan, S. Episodic Salinization and Freshwater Salinization Syndrome Mobilize Base Cations, Carbon, and Nutrients to Streams across Urban Regions. Biogeochemistry 141, 463-86 (2018).

[31] Shanley, J.B. Effects of ion-exchange on stream solute fluxes in a basin receiving highway deicing salts. J. Environ. Qual. 23, 977-986 (1994).

[32] Kaushal, S.S. Increased salinization decreases safe drinking water. Environ. Sci. Technol. 50, 27652766 (2016).

[33] Andrew Hong, P.K., Macauley, Y. Corrosion and Leaching of Copper Tubing Exposed to Chlorinated Drinking Water. Water, Air, \& Soil Pollution 108, 457-471 (1998).

[34] Nguyen, C.K., Stone, K.R., Edwards, M.A. Chloride-to-sulfate mass ratio: Practical studies in galvanic corrosion of lead solder. Journal - American Water Works Association 103, 81-92 (2011).

[35] Stets, E.G., Lee, C.J., Lytle, D.A., Schock, M.R. Increasing chloride in rivers of the conterminous U.S. and linkages to potential corrosivity and lead action level exceedances in drinking water. Science of The Total Environment 613-614, 1498-1509 (2018).

[36] Dietrich, A.M., Burlingame, G.A. Critical review and rethinking of USEPA Secondary Standards for maintaining organoleptic quality of drinking water. Environ. Sci. Technol. 49, 708-720 (2015).

[37] "Sodium in Drinking Water" in Guidelines for drinking-water quality, $2^{\text {nd }}$ ed., Vol 2. Health criteria and other supporting information. World Health Organization, Geneva, 1996.

[38] "Drinking Water Advisory: Consumer Acceptability Advice and Health Effects Analysis on Sodium" Environmental Protection Agency, Washington D.C. (2003), EPA 822-R-03-006.

[39] National Research Council. 2012. Water Reuse: Potential for Expanding the Nation's Water Supply through Reuse of Municipal Wastewater. Washington, DC: The National Academies Press.

[40] Rodriguez, C. et al. Indirect Potable Reuse: A Sustainable Water Supply Alternative. Int. J. Environ. Res. Public Health 6, 1174-1209 (2009).

[41] Mukherjee, M., Jensen, O. Making water reuse safe: A comparative analysis of the development of regulation and technology uptake in the US and Australia. Safety Science 121, 5-14 (2020).

[42] EPA, 2017. Potable Reuse Compendium. Produce by Office of Ground Water and Drinking Water, Office of Water, U.S. Environmental Protection Agency. Available at: https:/www.epa.gov/sites/production/files/2018-01/documents/potablereusecompendium 3.pdf (accessed 25/01/2019).

[43] U.S. Environmental Protection Agency National Water Reuse Action Plan - Draft https://www.epa.gov/waterreuse/draft-national-water-reuse-action-plan

[44] Martin, B., Via, S. Integrating Water Reuse Into the U.S. Water Supply Portfolio. Journal American Water Works Association 112, 9-14 (2020). 
[45] Government Accountability Office (2014) Freshwater: Supply concerns continue, and uncertainties complicate planning. (GAO-14-43). https://www.gao.gov/assets/670/663343.pdf

[46] Rice, J., Westerhoff, P. High levels of endocrine pollutants in US streams during low flow due to insufficient wastewater dilution. Nature Geoscience 10, 587-591 (2017).

[47] Weiner, M.J., Moreno, S. Jafvert, C., Nies, L.F. Time series analysis of water use and indirect reuse within a HUC-4 basin (Wabash) over a nine year period. Science of the Total Environment 738, 140221 (2020).

[48] Berger, E., Haase, P., Kuemmerlen, M., Leps, M., Schäfer, R. B., Sundermann, A. Water quality variables and pollution sources shaping stream macroinvertebrate communities. Science of the Total Environment 587, 1-10 (2017).

[49] Meybeck, M. Global analysis of river systems: from Earth system controls to Anthropocene syndromes. Philosophical Transactions of the Royal Society B: Biological Sciences 358, 1935-1955 (2003).

[50] Venkatesan, A.K., Ahmad, S., Johnson, W., Batista, J.R. Systems dynamic model to forecast salinity load to the colorado river due to urbanization within the las vegas valley. Sci. Total Environ. Res. Educat. Effectiv. 469, 2616-2625 (2011).

[51] Nimiroski, M.T., Waldron, M.C. Sources of sodium and chloride in the Scituate Reservoir drainage basin, RI. US Geological Survey Report WRIR-02-4149, March 2002.

[52] Jackson, R. B., Jobbágy, E. G. From icy roads to salty streams. Proc. Natl. Acad. Sci. U.S.A. 102, 14487-14488 (2005).

[53] Litalien, A., Zeeb, B. Curing the earth: A review of anthropogenic soil salinization and plant-based strategies for sustainable mitigation. Science of the Total Environment 698, 134235 (2019).

[54] Fitzpatrick, M.L., Long, D.T., Pijanowski, B.C. Exploring the effects of urban and agricultural land use on surface water chemistry, across a regional watershed using multivariate statistics. Appl. Geochem. 22,1825-40 (2007).

[55] Novotny, E.V., Sander, A., Mohseni, O., Heinz, S. Chloride ion transport and mass balance in a metropolitan area using road salt. Water Resources Research 45, (2009).

[56] Mullaney, J.R., Lorenz, D.L., Arntson, A.D. Chloride in groundwater and surface water in areas underlain by the glacial aquifer system, northern United States. US Geological Survey Scientific Investigations Report 2009-5086; 2009. p. 1-41.

[57] Potter J.D., McDowell W.H., Helton A.M., Daley M.L. Incorporating urban infrastructure into biogeochemical assessment of urban tropical streams in Puerto Rico. Biogeochemistry 121, 271-286 (2014).

[58] Kaushal, S.S., McDowell, W.H., Wollheim, W.M. Tracking evolution of urban biogeochemical cycles: past, present, and future. Biogeochemistry 121, 1-21 (2014).

[59] Kaushal, S.S. et al. Longitudinal patterns in carbon and nitrogen fluxes and stream metabolism along an urban watershed continuum. Biogeochemistry 121, 23-44 (2014).

[60] "Ambient Water Quality Criteria for Chloride" U.S. Environmental Protection Agency, Washington D.C. (1998), EPA 440/5-88-001.

[61] Rauch, W., Harremoës, P. The Importance of the Treatment Plant Performance during Rain to Acute Water Pollution. Water Science and Technology 34, 1-8 (1996).

[62] Rouleau, S., Lessard, P., Bellefleur, D. Behaviour of a small wastewater treatment plant during rain events. Can. J. Civ. Eng. 24, 790-798 (1997).

[63] McMahan, Erin K., "Impacts of Rainfall Events on Wastewater Treatment Processes" (2006).

Graduate Theses and Dissertations. http://scholarcommons.usf.edu/etd/3846

[64] Weiner, M.J., Moreno, S. Jafvert, C., Nies, L.F. Time series analysis of water use and indirect reuse within a HUC-4 basin (Wabash) over a nine year period. Science of the Total Environment 738, 140221 (2020).

[65] Nelsen, R.B. An Introduction to Copulas (Springer-Verlag New York, 2006).

[66] Lazarova, V., Asano, T., Bahri, A., Anderson, J. Milestones in Water Reuse: The Best Success Stories (IWA Publishing, London, 2013). 
[67] United States Census Bureau, Retrieved from https://data.census.gov/cedsci/

[68] Upper Occoquan Service Authority. 2017. Comprehensive Annual Financial Report. Retrieved from https://www.uosa.org/Documents/0450 012759.pdf

[69] Patterson, R. (10.1520/STP13784S). Domestic Wastewater and the Sodium Factor. In Bedinger, M., Fleming, J., and Johnson, A. (Ed.), STP1324-EB Site Characterization and Design of On-Site Septic Systems (pp. 35-1997). https://doi/org/978-0-8031-5376-9

[70] Allen, L., Christian-Smith, J., Palaniappan, M. "Overview of Greywater Reuse: The Potential of Greywater Systems to Aid Sustainable Water Management” Pacific Institute, Oakland, CA. 2010.

[71] Tjandraatmadja G, Diaper C, Gozukara Y, Burch L, Sheedy C and Price G "Sources of priority contaminants in domestic wastewater: Contaminant contribution from household products." CSIRO: Water for a Healthy Country National Research Flagship, 2008.

[72] Tran, Q. K., Jassby, D., Schwabe, K. A. The implications of drought and water conservation on the reuse of municipal wastewater: Recognizing impacts and identifying mitigation possibilities. Water Research, 124, 472-481(2017).

[73] Schwabe, K., Nemati, M., Amin, R., Tran, Q., Jassby, D. Unintended consequences of water conservation on the use of treated municipal wastewater. Nature Sustainability 3, 628-635 (2020). [74] Consonni, V., Ballabio, D., Todeschini, R. Evaluation of model predictive ability by external validation techniques. Journal of Chemometrics 24, 194-201(2010).

[75] Kiralj, R., Ferreira, M. Basic validation procedures for regression models in QSAR and QSPR studies: theory and application. Journal of the Brazilian Chemical Society 20, 770-787 (2009).

[76] Schüürmann, G., Ebert, R., Chen, J., Wang, B., Kühne, R. External validation and prediction employing the Predictive Squared Correlation Coefficient - Test Set Activity Mean vs Training Set Activity Mean. Journal of Chemical Information and Modeling 48, 2140-2145 (2008).

[77] Good, N. et al. Development and validation of models to predict personal ventilation rate for air pollution research. J Expo Sci Environ Epidemiol 29, 568-577 (2019).

[78] Schädel, C. et al. Potential carbon emissions dominated by carbon dioxide from thawed permafrost soils. Nature Clim Change 6, 950-953 (2016).

[79] Cogswell, M.E. et al. Estimated 24-Hour Urinary Sodium and Potassium Excretion in U.S. Adults. JAMA 319, 1209-1220 (2018).

[80] Gleick, P.H. Global freshwater resources: Soft-path solutions for the $21^{\text {st }}$ Century. Science 302, 1524-1528 (2003).

[81] Grant, S.B. et al. Taking the 'Waste' out of 'Wastewater". Science 337, 681-686 (2012).

[82] Katz, B.G., Eberts, S.M., Kauffman, L.J. Using C1/Br ratios and other indicators to assess potential impacts on groundwater quality from septic systems: a review and examples from principal aquifers in the United States. J. Hydrol. 397, 151-166 (2011).

[83] Kaushal, S.S. et al. Human-Accelerated Weathering Increases Salinization, Major Ions, and Alkalinization in Fresh Water across Land Use. Applied Geochemistry, Urban Geochemistry 83, 121-35 (2017).

[84] Albers, Tregan P.D. II. (2015) "Best Practices for Winter Maintenance Roadway Deicer Applications in the State of Nebraska". Civil Engineering Theses, Dissertations, and Student Research. 80. http://digitalcommons.unl.edu/civilengdiss/80

[85] Di Baldassarre, G. et al. Sociohydrology: Scientific challenges in addressing the sustainable development goals. Water Resources Research 55, 6327-6355 (2019).

[86] Su, J.G. et al. Factors influencing whether children walk to school. Health Place, 22, 153-161 (2013).

[87] Micron Technology, Inc. (2018, August 29). Micron Announces Investment in its Semiconductor Manufacturing Plant in Manassas, VA [Press release]. https://investors.micron.com/node/37386/pdf

[88] "Wastewater Technology Fact Sheet: Chlorine Disinfection", U.S Environmental Protection Agency, Washington D.C. (1999), EPA832-F-99-062.

[89] "Wastewater Technology Fact Sheet: Dechlorination", U.S Environmental Protection Agency, Washington D.C. (2000), EPA832-F-00-022. 
[90] Lazarova, V., Savoye, P., Janex, M.L., Blatchley III, E.R., Pommepuy, M. Advanced wastewater disinfection technologies: state of the art and perspectives. Water Science and Technology 40, 203-213 (1999).

[91] Davis, M. L. Water and wastewater engineering: design principles and practice. (McGraw-Hill, 2010).

[92] Potts, J. The innovation deficit in public services: The curious problem of too much efficiency and not enough waste and failure. Innovation, 11, 23-43 (2009).

[93] Kiparsky, M., Sedlak, D.L., Thompson Jr., B.H., Truffer, B. The innovation deficit in urban water: The need for an integrated perspective on institutions, organizations and technology. Environ. Eng. Sci. 30, 395-408 (2013).

[94] Kiparsky, M., Thompson, B.H., Binz, C., Sedlak, D.L. Tummers, L., Truffer, B. Barriers to innovation in urban wastewater utilities: Attitudes of managers in California. Environ. Management 57, 1204-1216 (2016).

[95] McKenzie-Mohr, D., Lee, N.R., Schultz, P.W., Kotler, P. Social Marketing to Protect the

Environment: What Works. (Sage Publications, Inc., 2011) 256 pp.

[96] Calcagno, V. (2020) Package "glmulti." Retrieved from https://cran.rproject.org/web/packages/glmulti/glmulti.pdf

[97] Guyon, I. A Scaling Law for the Validation-set Training-set Size Ratio, AT\&T Bell Laboratories (1997), pp. 1-11

[98] Ruppert, D. Statistics and Data Analysis for Financial Engineering. (Springer, 2011).

[99] Schwarz, G. Estimating the dimension of a model. The Annals of Statistics 6, 461-464 (1978).

[100] Efron, B. The jackknife, the bootstrap, and other resampling plans (Society for Industrial and Applied Mathematics, PA, USA, 1982) 91pp.

[101] Appling, A.P., Leon, M.C., McDowell, W.H. Reducing bias and quantifying uncertainty in watershed flux estimates: the R package loadflex. Ecosphere 6, Article 269 (2015).

[102] Schwarz, G. Estimating the dimension of a model. The Annals of Statistics 6, 461-464 (1978).

[103] Madadgar, S., AghaKouchak, A., Farahmand, A., Davis, S.J. Probabilistic estimates of drought impacts on agricultural production. Geophys. Res. Lett. 44, 7799-7807 (2017).

[104] Sadegh, M., Ragno, E., AghaKouchak, A. Multivariate Copula Analysis Toolbox (MvCAT): Describing dependence and underlying uncertainty using a Bayesian framework. Water Resources Research 53, 5166-5183 (2017).

[105] Trapletti, A., Hornik, K. (2019). tseries: Time Series Analysis and Computational Finance. R package version 0.10-47. Retrieved from https://CRAN.R-project.org/package=tseries

[106] Said, S. E., Dickey, D. A. Testing for unit roots in autoregressive-moving average models of unknown order. Biometrika 71, 599-607 (1984).

[107] Phillips, P. C. B., Perron, P. Testing for a unit-root in time-series regression. Biometrika 75, 335346 (1988).

[108] Kwiatkowski, D., Phillips, P. C. B., Schmidt, P., Shin, Y. Testing the Null Hypothesis of Stationarity against the Alternative of a Unit Root. Journal of Econometrics 54, 159-178 (1992).

[109] Solakian, J., Maggioni, V., Lodhi, A., Godrej, A. Investigating the use of satellite-based precipitation products for monitoring water quality in the Occoquan Watershed. Journal of Hydrology: Regional Studies 26, 100630 (2019). https://doi.org/10.1016/j.ejrh.2019.100630

[110] Shammas, N. K., Wang, L. K. Water engineering: hydraulics, distribution and treatment. (John Wiley \& Sons, 2016).

[111] American Water Works Association (AWWA). Water Quality \& Treatment (1999) A Handbook of Community Water Supplies. Editor: Raymond D. Letterman.

[112] Wiest, M., Fox, P., Lee, W., Thomure, T. (2011) Evaluation of Alternatives to Domestic Ion Exchange Water Softeners. Proceedings of the 84th Annual Water Environment Federation Technical Exposition and Conference; Los Angeles, California, Oct 10-13; Water Environment Federation: Alexandria, Virginia. 
[113] Wang, F., Devine, C. L., Edwards, M. A. Effect of Corrosion Inhibitors on In Situ Leak Repair by Precipitation of Calcium Carbonate in Potable Water Pipelines. Environmental Science \& Technology 51, 8561-8568 (2017).

[114] Richards, C. S., Wang, F., Becker, W. C., Edwards, M. A. A 21st-Century Perspective on Calcium Carbonate Formation in Potable Water Systems. Environmental Engineering Science 35, 143-158 (2018).

[115] Rehring, J. P., Edwards, M. Copper Corrosion in Potable Water Systems: Impacts of Natural Organic Matter and Water Treatment Processes, Corrosion, 52, 307-317 (1996).

[116] Nguyen, C. K., Stone, K. R., Clark, B., Gagnon, G., Knowles, A., Edwards, M. A. Impact of Chloride:Sulfate Mass Ratio (CSMR) Changes on Lead Leaching in Potable Water. 4088; Water Research Foundation: Denver, CO, 2010.

[117] Dotson, A. D., Rodriguez, C. E., Linden, K. G. UV disinfection implementation status in US water treatment plants. Journal - American Water Works Association 104, E318-E324 (2012).

[118] Collivignarelli, M. C., Abbà, A., Benigna, I., Sorlini, S., Torretta, V. Overview of the main disinfection processes for wastewater and drinking water treatment plants. Sustainability 10, 86 (2018).

[119] Tang, M. et al. The relationship between discolored water from corrosion of old iron pipe and source water conditions. Environmental Engineering Science 35, 943-952 (2018).

[120] Benjamin, L., Green, R., Smith, A., Summerer, S. Pilot Testing a Limestone Contactor in British Columbia. Journal - American Water Works Association, 84, 70-79 (1992).

[121] Sahu, O.P., Chaudhari, P.K. Review on Chemical treatment of Industrial Waste Water. J. Appl. Sci. Environ. Manage. 17, 241-257 (2013).

[122] American Water Works Association (AWWA) and American Society of Civil Engineers (ASCE). Water treatment plant design. (McGraw-Hill, U.S., Third edition, 1990) 806 p.

[123] Eriksson, L. et al. Methods for reliability and uncertainty assessment and for applicability evaluations of classification- and regression-based QSARs. Environmental health perspectives, 111, 1361-1375 (2003).

[124] Palachy, S. (2019, April 8) Stationarity in time series analysis [Blog post]. Retrieved from https://towardsdatascience.com/stationarity-in-time-series-analysis-90c94f27322

[125] Palachy, S. (2019, July 21) Detecting stationarity in time series data [Blog post]. Retrieved from https://towardsdatascience.com/detecting-stationarity-in-time-series-data-d29e0a21e638

[126] Glen, S. "Unit Root: Simple Definition, Unit Root Tests" From StatisticsHowTo.com: Elementary Statistics for the rest of us! https://www.statisticshowto.com/unit-root/

[127] Bhide, S. (2020). Occoquan Watershed Data, HydroShare, http://www.hydroshare.org/resource/61a19724394643fca62a4fb3ce881efe 


\section{Figures}
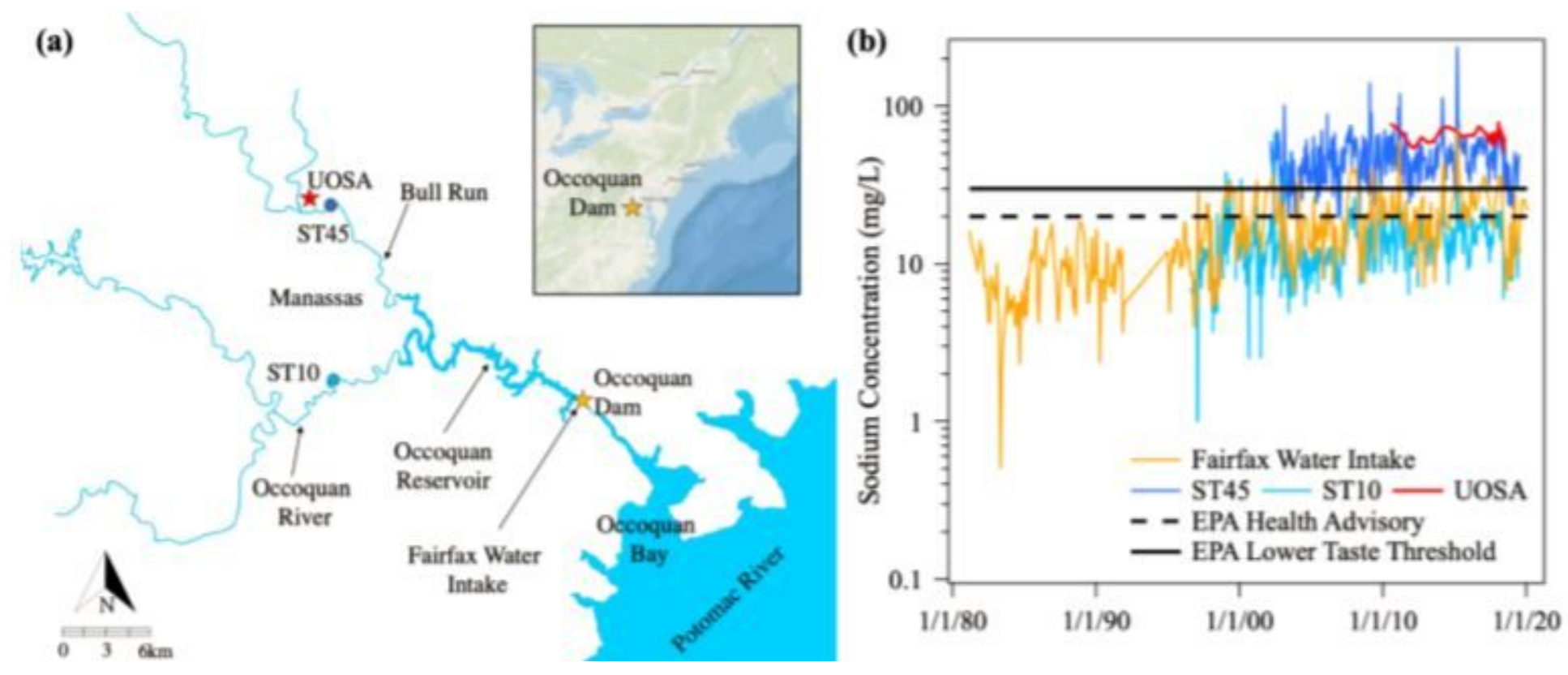

\section{Figure 1}

(a) The Occoquan Reservoir in Northern Virginia, USA. More than 95\% freshwater inflow to the reservoir is from the Occoquan River and Bull Run which drain mixed undeveloped, agriculture, ex urban and urban landscapes. Shown are key geographical features including the Occoquan Dam (where Fairfax Water sources its raw water), ion and flow monitoring sampling sites on the Occoquan River and Bull Run (monitoring stations ST10 and ST45), and the location on Bull Run where reclaimed water is discharged from the Upper Occoquan Service Authority (UOSA). Water from the Occoquan Reservoir is treated by Fairfax Water, the water wholesaler, and from there passes to various water distributors. (b) Forty years of sodium concentration measurements at the Fairfax Water intake and upstream stations ST10, ST45), and the final reclaimed water discharged by UOSA. Also shown are the EPA Health Advisory and Lower Taste Threshold for sodium. 

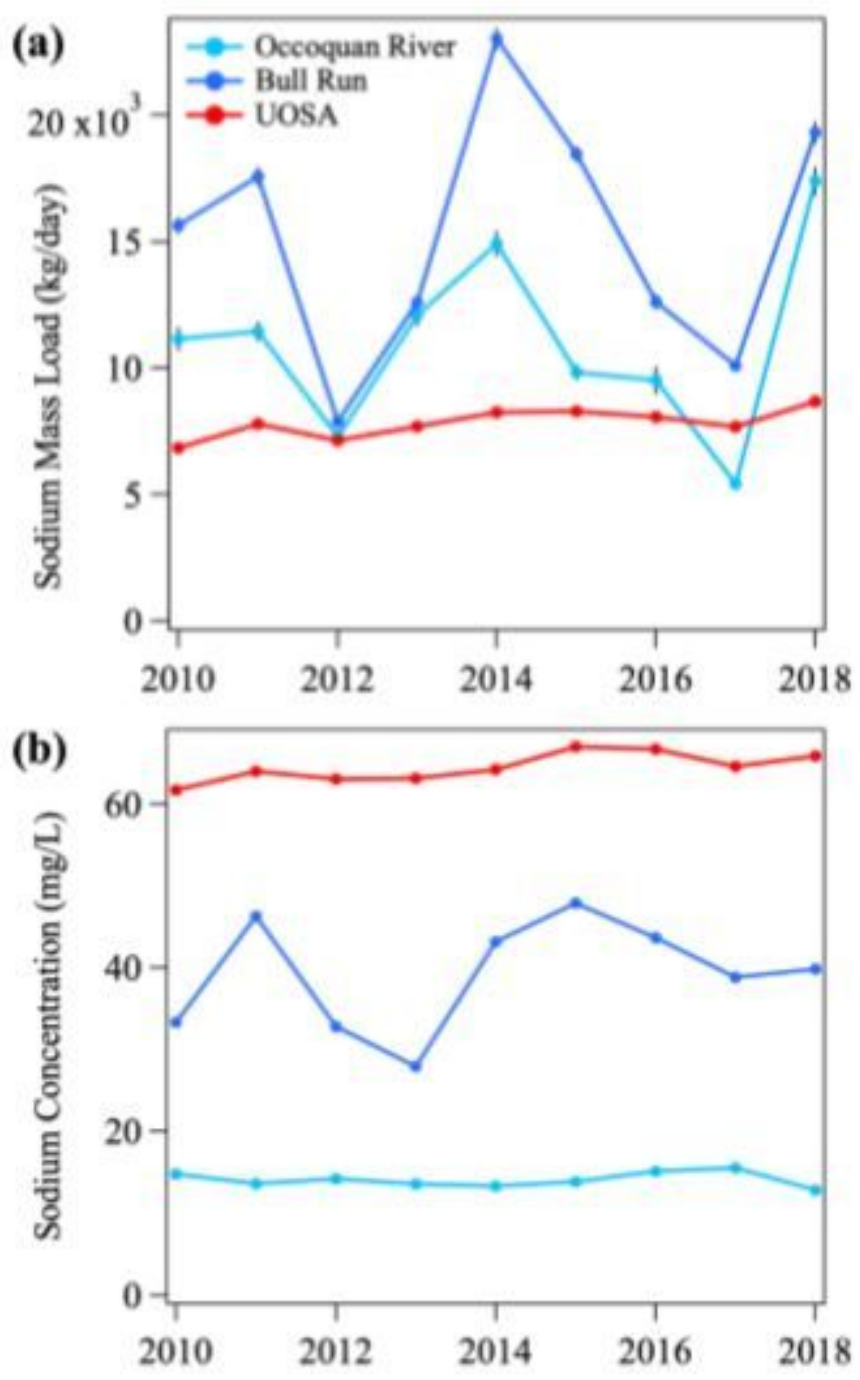

Figure 2

(a) Annualized sodium mass loads and (b) sodium concentration from Occoquan River, Bull Run and UOSA water reclamation facility. 


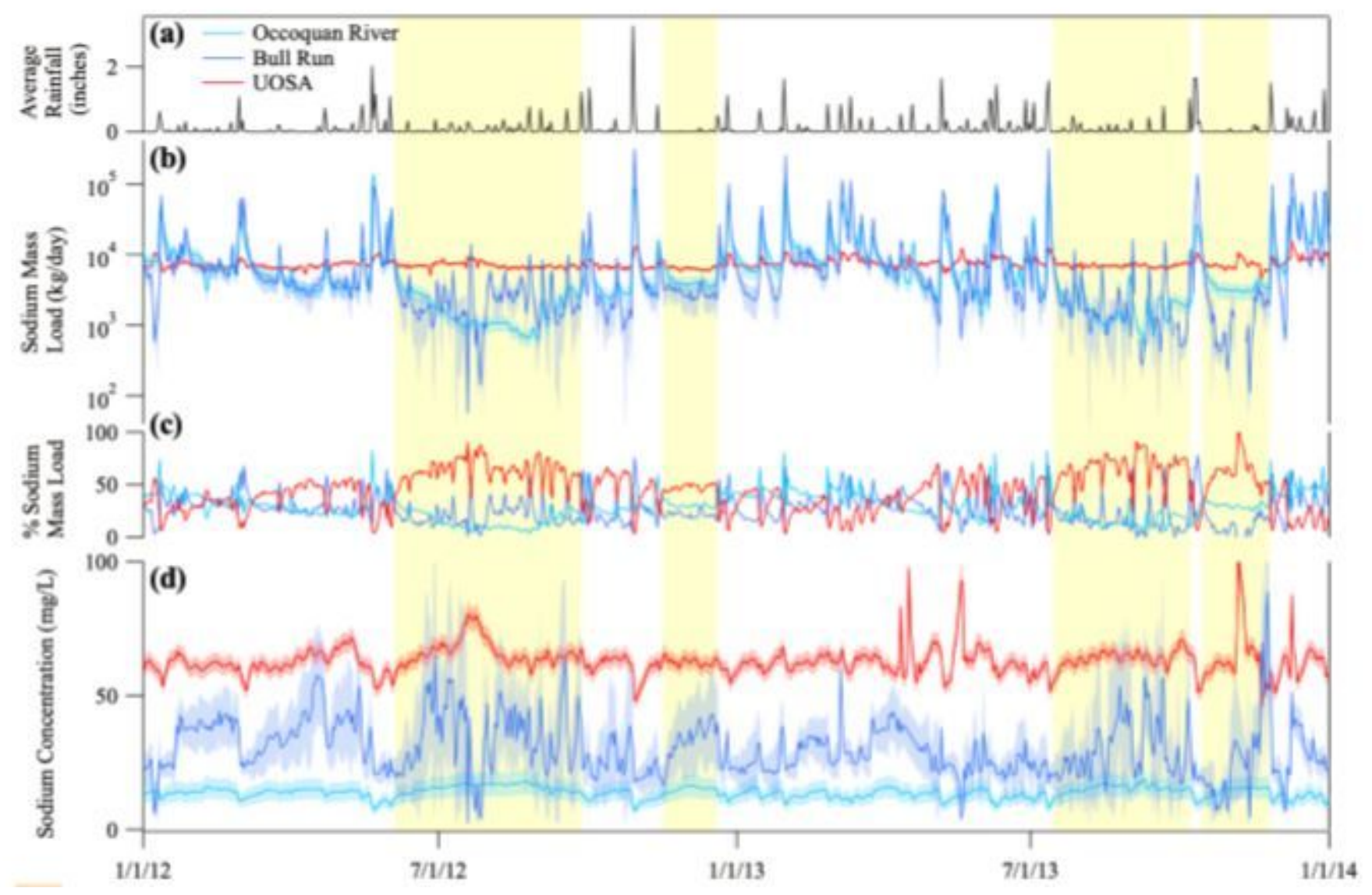

Figure 3

(a) Daily average rainfall in the watershed, (b) daily realizations of sodium mass load, (c) percentage of total sodium mass load and (d) daily realizations of sodium concentration from the Occoquan River, Bull Run and UOSA respectively for an illustrative two-year period (2012-2013).

Low Flow (90 cfs)

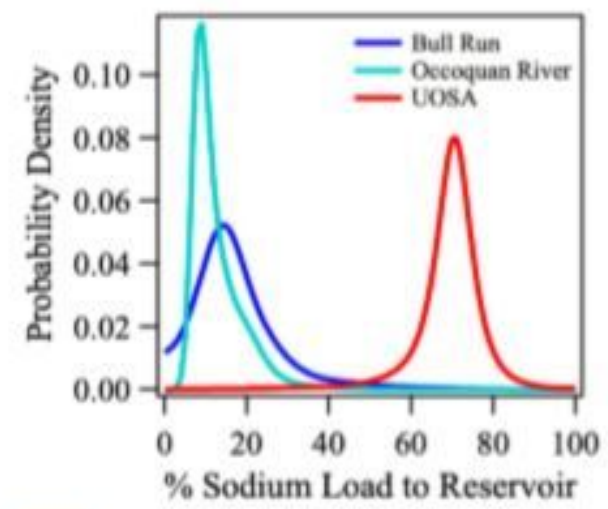

Median Flow (244 cfs)

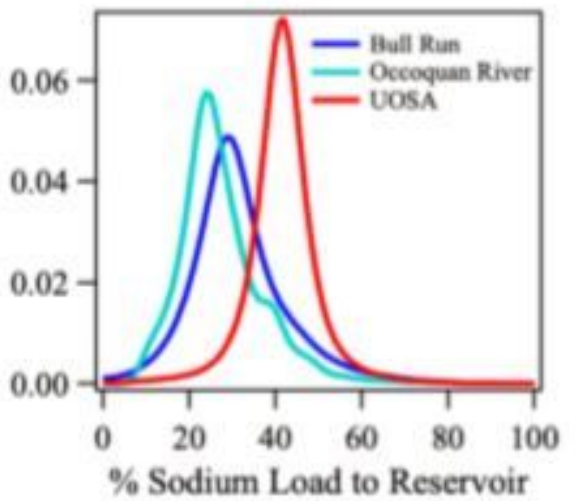

High Flow (1095 cfs)

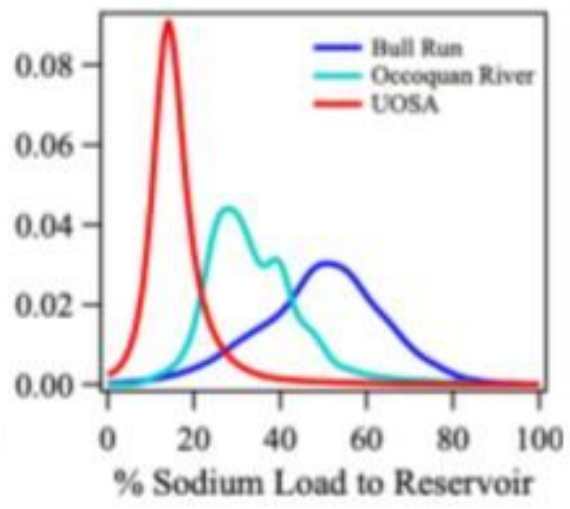

\section{Figure 4}

Probability density functions (PDFs) of sodium mass loads conditioned on low, medium and high flow into the reservoir (columns 1,2 and 3 respectively; cfs = cubic feet per second). The salient feature of each 
curve is the range of values on the horizontal axis for which there is non-zero probability density. The peak height of each curve is determined by the unit area of the PDF.

(a)

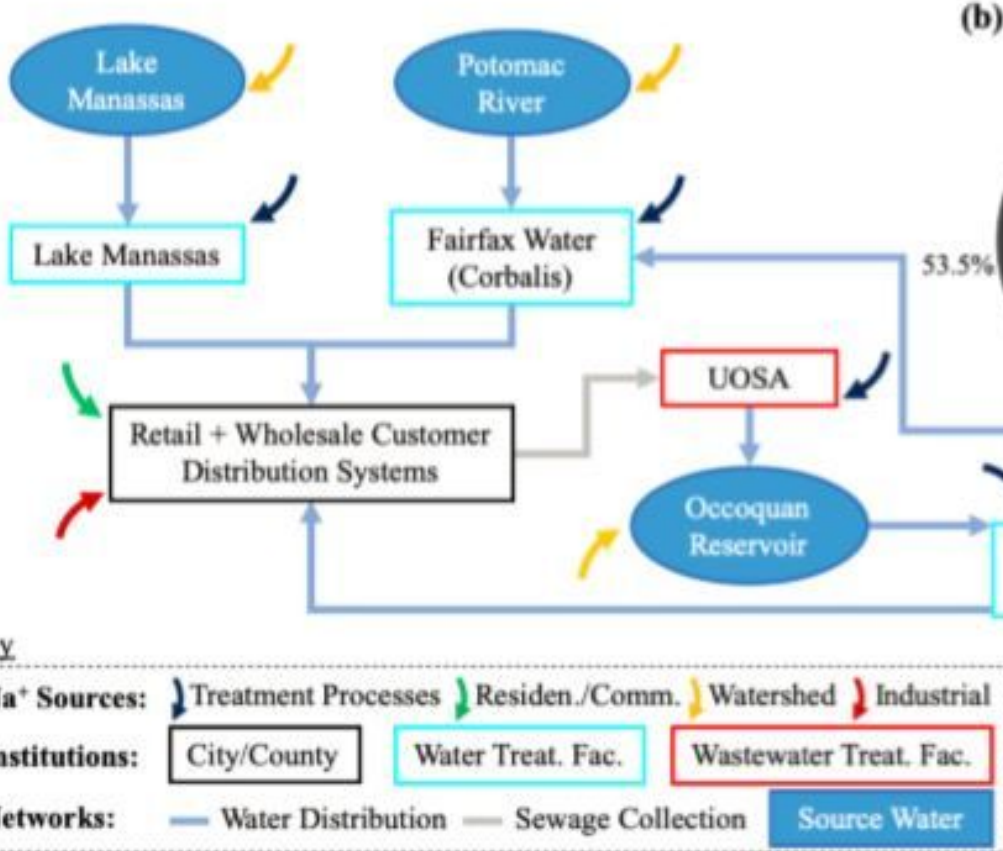

\section{Key

\begin{tabular}{|c|c|c|c|}
\hline \multirow{2}{*}{$\begin{array}{l}\mathrm{Na}^{+} \text {Sources: } \\
\text { Institutions: }\end{array}$} & \multicolumn{3}{|c|}{ Treatment Processes $/$ Residen./Comm. } \\
\hline & City/County & Water Treat. Fac. & Wastewater Treat. Fac. \\
\hline Networks: & - Water Dis & ion - Sewage & Source Water \\
\hline
\end{tabular}

(b)

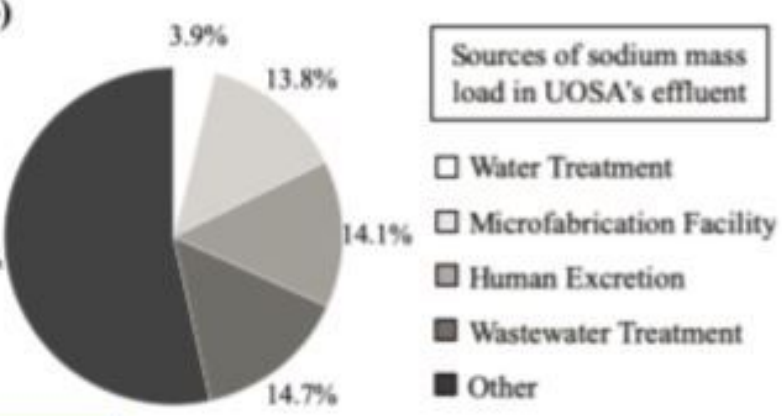

Fairfax Water (Griffith)

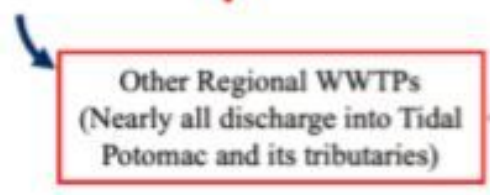

\section{Figure 5}

(a) Schematic representation of the drinking water and sewage collection network for the Occoquan watershed and surrounding area. Under normal conditions, the portion of the sewage network draining to UOSA receives water from the Fairfax Water's Corbalis water treatment plant, although some water from Fairfax Water's Griffith water treatment plant may also contribute to UOSA's inflow (forming a systemscale semi-closed loop for the circulation of sodium through the Occoquan Reservoir). (b) Source breakdown for the annual sodium load in UOSA's reclaimed water.

\section{Supplementary Files}

This is a list of supplementary files associated with this preprint. Click to download.

- BhideSl81620.pdf 